\title{
Title: Amphibian fungal panzootic causes catastrophic and ongoing loss of
}

\section{biodiversity}

Authors: Ben C. Scheele ${ }^{1,2,3 *}$, Frank Pasmans ${ }^{4}$, Lee F. Skerratt ${ }^{3}$, Lee Berger ${ }^{3}$, An Martel ${ }^{4}$, Alessandro Catenazzi ${ }^{9}$, Ignacio De la Riva ${ }^{10}$, Matthew C. Fisher ${ }^{11}$, Sandra V. Flechas ${ }^{12,13}$, Claire N. Foster ${ }^{1}$, Patricia Frías-Álvarez ${ }^{3}$, Trenton W. J. Garner ${ }^{14}$, Brian Gratwicke ${ }^{15}$, Juan M. Guayasamin $^{16,17,18}$, Mareike Hirschfeld ${ }^{19}$, Jonathan E. Kolby ${ }^{3,20,21}$, Tiffany A. Kosch ${ }^{3}$, Enrique La Marca ${ }^{22}$, David B. Lindenmayer ${ }^{1,2}$, Karen R. Lips ${ }^{23}$, Ana V. Longo ${ }^{24}$, Raul Maneyro ${ }^{25}$, Cait A. McDonald ${ }^{26}$, Joseph Mendelson III ${ }^{27,28}$, Pablo Palacios-Rodriguez ${ }^{12}$, Gabriela Parra-Olea ${ }^{29}$, Corinne L. Richards-Zawacki ${ }^{30}$, Mark-Oliver Rödel ${ }^{19}$, Sean M. Rovito ${ }^{31}$, Claudio Soto-Azat ${ }^{32}$, Luís Felipe Toledo ${ }^{8}$, Jamie Voyles $^{33}$, Ché Weldon ${ }^{34}$, Steven M. Whitfield ${ }^{35}$, Mark Wilkinson ${ }^{36}$, Kelly R. Zamudio ${ }^{26}$, Stefano Canessa ${ }^{4}$

\section{Affiliations:}

${ }^{1}$ Fenner School of Environment and Society, Australian National University, Canberra, ACT 2601, Australia.

${ }^{2}$ National Environmental Science Programme, Threatened Species Recovery Hub, Australia.

${ }^{3}$ One Health Research Group, Melbourne Veterinary School, The University of Melbourne, Werribee 3030, Victoria, Australia.

${ }^{4}$ Wildlife Health Ghent, Department of Pathology, Bacteriology and Avian Diseases, Faculty of Veterinary Medicine, Ghent University, B-9820 Merelbeke, Belgium. 
${ }^{5}$ Programa de Doctorado en Ciencias Biológicas, Laboratorio de Biología Evolutiva, Pontificia Universidad Católica de Chile, Avenida Libertador Bernardo O’Higgins 340, Santiago, Chile.

${ }^{6}$ Grupo de Investigación en Ecología y Biogeografía, Universidad de Pamplona, Barrio El Buque, Km 1, Vía a Bucaramanga, Pamplona, Colombia.

${ }^{7}$ Department of Biology, University of Puerto Rico, San Juan, P.O. Box 23360, Puerto Rico.

${ }^{8}$ Laboratório de História Natural de Anfíbios Brasileiros (LaHNAB), Departamento de Biologia Animal, Instituto de Biologia, Universidade Estadual de Campinas, Campinas, Brazil.

${ }^{9}$ Department of Biological Sciences, Florida International University, Miami, Florida 33199, USA.

${ }^{10}$ Museo Nacional de Ciencias Naturales-CSIC, C/ José Gutiérrez Abascal 2, Madrid 28006, Spain.

${ }^{11}$ MRC Centre for Global Infectious Disease Analysis, School of Public Health, Imperial College London, London W2 1PG, UK.

${ }^{12}$ Department of Biological Sciences, Universidad de los Andes, Bogotá, Colombia.

${ }^{13}$ Instituto de Investigación de Recursos Biológicos Alexander von Humboldt, Sede Venado de Oro, Paseo Bolívar 16-20, Bogotá, Colombia.

${ }^{14}$ Institute of Zoology, Zoological Society London, Regents Park, London NW1 4RY, UK.

${ }^{15}$ Smithsonian National Zoological Park and Conservation Biology Institute, Washington 20008, USA.

$20 \quad{ }^{16}$ Universidad San Francisco de Quito USFQ, Colegio de Ciencias Biológicas y Ambientales COCIBA, Instituto de Investigaciones Biológicas y Ambientales BIOSFERA, Laboratorio de Biología Evolutiva, Campus Cumbayá, Quito, Ecuador. 
${ }^{17}$ Centro de Investigación de la Biodiversidad y Cambio Climático (BioCamb), Ingeniería en Biodiversidad y Cambio Climático, Facultad de Medio Ambiente, Universidad Tecnológica Indoamérica, Calle Machala y Sabanilla, Quito, Ecuador.

${ }^{18}$ Department of Biology, Colorado State University, Fort Collins, Colorado, USA.

${ }^{19}$ Museum für Naturkunde, Leibniz Institute for Evolution and Biodiversity Science, Invalidenstr. 43, Berlin 10115, Germany.

${ }^{20}$ Honduras Amphibian Rescue and Conservation Center, Lancetilla Botanical Garden and Research Center, Tela, Honduras.

${ }^{21}$ The Conservation Agency, Jamestown, Rhode Island 02835, USA.

${ }^{22}$ School of Geography, Faculty of Forestry Engineering and Environmental Sciences, University of Los Andes, Merida, Venezuela.

${ }^{23}$ Department of Biology, University of Maryland, Maryland 20742, USA.

${ }^{24}$ Department of Biology, University of Florida, Florida 32611, USA.

${ }^{25}$ Laboratorio de Sistemática e Historia Natural de Vertebrados. Facultad de Ciencias, Universidad de la República. Igua 4225, CP 11400, Montevideo, Uruguay.

${ }^{26}$ Department of Ecology and Evolutionary Biology, Cornell University, Ithaca, New York 14853, USA.

${ }^{27}$ Zoo Atlanta, Atlanta, Georgia 30315 USA.

${ }^{28}$ School of Biological Sciences, Georgia Institute of Technology, Atlanta, Georgia 30332, USA.

$20{ }^{29}$ Departamento de Zoología, Instituto de Biología, Universidad Nacional Autónoma de México, Mexico City, México. 
${ }^{30}$ Department of Biological Sciences, University of Pittsburgh, Pittsburgh, Pennsylvania, USA.

${ }^{31}$ Unidad de Genómica Avanzada (Langebio), Centro de Investigación y de Estudios Avanzados del Instituto Politécnico Nacional, km 9.6 Libramiento Norte Carretera Irapuato-León, Irapuato, Guanajuato CP36821, México.

${ }^{32}$ Centro de Investigación para la Sustentabilidad, Facultad de Ciencias de la Vida, Universidad Andres Bello, Santiago 8370251, Chile.

${ }^{33}$ Department of Biology, University of Nevada, Reno, Nevada, USA.

${ }^{34}$ Unit for Environmental Sciences and Management, North-West University, Potchefstroom 2520, South Africa.

35 Zoo Miami, Conservation and Research Department, Miami, Florida 33177, USA.

${ }^{36}$ Department of Life Sciences, The Natural History Museum, London SW7 5BD, UK.

*Correspondence to: ben.scheele@ anu.edu.au (B.C.S.)

\section{Abstract:}

Anthropogenic trade and development have broken down dispersal barriers, facilitating the spread of diseases that threaten Earth's biodiversity. We present a global, quantitative assessment of the amphibian chytridiomycosis panzootic, one of the most impactful examples of disease spread, and demonstrate its role in the decline of at least 501 amphibian species over the last half century, including 90 presumed extinctions. The effects of chytridiomycosis have been greatest in range-restricted anurans, wet climates, and high elevations in the Americas and Australia. 
Declines peaked in the 1980 s and only $12 \%$ of declined species show signs of recovery, while $39 \%$ are experiencing ongoing decline. There is risk of further chytridiomycosis outbreaks in new areas. The chytridiomycosis panzootic represents the greatest recorded loss of biodiversity attributable to a disease.

\section{One Sentence Summary:}

The amphibian disease chytridiomycosis has driven the greatest loss of biodiversity attributable to a pathogen.

Main Text:

Highly virulent wildlife diseases are contributing to the Earth's sixth mass extinction (1). One of these is chytridiomycosis, which has caused mass amphibian die-offs worldwide $(2,3)$. Chytridiomycosis is caused by two fungal species, Batrachochytrium dendrobatidis (discovered in 1998, 4) and B. salamandrivorans (discovered in 2013, 5). Both Batrachochytrium species likely originated in Asia and their recent spread has been facilitated by humans $(5,6)$. Twenty years after the discovery of chytridiomycosis, substantial research has yielded insights about its epidemiology $(2,3,7,8)$, yet major knowledge gaps remain. First, the global extent of species declines associated with chytridiomycosis is unknown (see 2, 9 for initial assessments). Second, although some regional declines are well studied, global spatial and temporal patterns of chytridiomycosis impacts remain poorly quantified. Third, ecological and life history traits have been examined only for a portion of declined species $(10,11)$. Finally, following initial declines, it is unknown what proportion of declined species exhibit recovery, stabilize at lower abundance, 
or continue to decline. Here we present a global epidemiological analysis of the spatial and temporal extent of amphibian biodiversity loss caused by chytridiomycosis.

We conducted a comprehensive examination of evidence from multiple sources, including the IUCN Red List of Threatened Species (12), peer-reviewed literature, and consultation with amphibian experts worldwide (data S1). We classified declined species into five decline severity categories corresponding to reductions in abundance. Species declines were attributed to chytridiomycosis based on diagnosis of infection causing mortalities in the wild, or if this was unavailable, evidence consistent with key epidemiological characteristics of this disease. Most evidence is retrospective because many species declined before the discovery of chytridiomycosis (data S1).

We conservatively report chytridiomycosis has contributed to the decline of at least 501 amphibian species (6.5\% of described amphibian species; Figs. 1, 2). This represents the greatest documented loss of biodiversity attributable to a pathogen, and places $B$. dendrobatidis among the most destructive invasive species, comparable to rodents (threatening 420 species) and cats (Felis catus) (threatening 430 species) (13). Losses associated with chytridiomycosis are orders of magnitude greater than for other high-profile wildlife pathogens, such as white-nose syndrome (Pseudogymnoascus destructans) in bats (six species) (14) or West Nile virus (Flavivirus sp.) in birds (23 species) (15). Of the 501 declined amphibian species, 90 (18\%) are confirmed or presumed extinct in the wild, with a further 124 (25\%) experiencing a $>90 \%$ reduction in abundance (Figs. 1, 2). All except one species' decline (Salamandra salamandra affected by $B$. salamandrivorans) were attributed to B. dendrobatidis.

Declines were proportional to taxonomic abundance, with anurans having $93 \%$ of severe declines (they comprise $89 \%$ of all amphibian species). Within anurans, there has been marked 
taxonomic clustering of declines, with $45 \%$ of severe declines and extinctions occurring in the Neotropical genera Atelopus, Craugastor and Telmatobius (Fig. 2) (16). Chytridiomycosis is lethal to caecilians (17), but there have been no caecilian declines due to the disease, although data are limited. The capacity for $B$. dendrobatidis to cause major declines is attributable to its maintenance of high pathogenicity $(2,18)$, broad host range $(8)$, high transmission rate within and among host species $(2,7)$, and persistence in reservoir host species and the environment (19). For many species, chytridiomycosis is the principal driver of decline, exemplified by precipitous mass mortalities in undisturbed environments (2). In other species, chytridiomycosis acts in concert with habitat loss, altered climatic conditions, and invasive species to exacerbate species declines $(20)$.

Most amphibian declines have occurred in the tropics of Australia, Mesoamerica and South America (Fig. 1), supporting the hypothesis that B. dendrobatidis spread from Asia into the New World (6). Asia, Africa, Europe and North America have had remarkably low numbers of declines attributable to chytridiomycosis, despite widespread occurrence of $B$. dendrobatidis (8). Relative lack of documented declines could reflect less knowledge of amphibian populations in Asia and Africa $(3,21)$, early introduction and potential coevolution of amphibians and $B$. dendrobatidis in parts of Africa and the Americas (e.g. (22)), the comparatively recent emergence of B. dendrobatidis in Western and Northeast Africa (6), or unsuitable conditions for chytridiomycosis. It remains unknown whether chytridiomycosis contributed to widespread amphibian declines reported in North America and Europe in the 1950-1960s $(3,21,22)$ or current enigmatic salamander declines in eastern North America. While the number of new declines has now eased (Fig. 3), additional declines could occur if B. dendrobatidis or $B$. salamandrivorans are introduced into new areas, highly virulent lineages are introduced into 
areas that currently have less virulent lineages (6), and/or environmental changes alter previously stable pathogen-host dynamics (3).

Chytridiomycosis-associated declines peaked globally in the 1980s, between one and two decades prior to the discovery of the disease (Fig. 3, and table S1), and coincident with anecdotal recognition of amphibian declines in the 1990s (23). A second, smaller peak occurred in the early 2000s, associated with an increase in declines in western South America (Fig. 3, and fig. S1). Regionally, temporal patterns of decline are variable (fig. S1). For example, in some areas of South America and Australia, declines commenced in the late 1970s (2, 24), while in other areas, declines started in the 2000s (25). Batrachochytrium dendrobatidis is associated with ongoing declines in 197 assessed species. Ongoing declines after a transition to enzootic disease dynamics (19) might be driven by a lack of effective host defences, maintenance of high pathogenicity (18), and presence of $B$. dendrobatidis in amphibian and non-amphibian reservoirs (7, 19).

We examined host life-history traits and environmental conditions to understand why some species declined more severely than others, using multinomial logistic regression and accounting for the degree of evidence that chytridiomycosis was implicated in each species' decline (fig. S2 and table S2). Decline severity was greatest for larger-bodied species, those occurring in consistently wet regions, and those strongly associated with perennial aquatic habitats. These patterns are likely due to favourable environmental conditions for $B$. dendrobatidis in wet regions (7), because the fungus dies when desiccated, as well as the general pattern of increased time to maturity in large bodied amphibians resulting in less reproductive potential to offset mortality due to chytridiomycosis (26). Declines were less severe for species with large geographic and elevational ranges (Fig. 4), potentially due to the greater chance of 
their range encompassing environmental conditions unfavourable for $B$. dendrobatidis (3), and/or information bias, as population extinctions can be assessed with more certainty in restrictedrange species. Our results are consistent with previous studies showing the risk of chytridiomycosis is associated with host aquatic habitat use, large body size and narrow elevational range $(10,11)$.

Encouragingly, of the 292 surviving species for which population trends are known, 60 (20\%) have shown initial signs of recovery. However, recoveries generally represent small increases in abundance of individual populations, not complete recovery at the species level. Logistic regression showed the probability of recovery was lower for species that experienced more recent or more severe declines, for large-bodied or nocturnal species, and for species occurring at higher elevations (fig. S2 and table S3). When holding those predictors of recovery at their mean value, the chances of a species recovering from a severe $(>90 \%)$ decline were less than one in ten. Low probability of recovery for high elevation species might be related to suitable climatic conditions for fungal persistence, as well as limited connectivity to source populations, and/or longer host generation time (26). Some recoveries may be underpinned by selection for increased host resistance (18), while management of concurrent threats may have facilitated other recoveries (a promising avenue for conservation interventions) (27). Unfortunately, the remaining 232 species have shown no signs of recovery.

The unprecedented lethality of a single disease affecting an entire vertebrate class highlights the threat from the spread of novel pathogens in a globalized world. Global trade has recreated a functional Pangaea for infectious diseases in wildlife, with far reaching impacts on biodiversity (this study), livestock (28), and human health (29). Effective biosecurity and an immediate reduction in wildlife trade are urgently needed to reduce the risk of novel pathogen 
spread. As mitigation of chytridiomycosis in nature remains unproven (30), new research and intensive monitoring utilizing emerging technologies is needed to identify mechanisms of species recovery and develop novel mitigation actions for declining species. 
References and Notes (references 1-30 cited in main text)

1. M. C. Fisher et al., Emerging fungal threats to animal, plant and ecosystem health. Nature 484, 186-194 (2012).

2. L. F. Skerratt et al., Spread of chytridiomycosis has caused the rapid global decline and extinction of frogs. EcoHealth 4, 125-134 (2007).

3. K. R. Lips, Overview of chytrid emergence and impacts on amphibians. Phil. Trans. R. Soc. B 371, 20150465 (2016).

4. L. Berger et al., Chytridiomycosis causes amphibian mortality associated with population declines in the rain forests of Australia and Central America. Proc. Natl. Acad. Sci. USA 95, 9031-9036 (1998).

5. A. Martel et al., Recent introduction of a chytrid fungus endangers Western Palearctic salamanders. Science 346, 630-631 (2014).

6. S. J. O'Hanlon et al., Recent Asian origin of chytrid fungi causing global amphibian declines. Science 360, 621-627 (2018).

7. T. Y. James et al., Disentangling host, pathogen, and environmental determinants of a recently emerged wildlife disease: lessons from the first 15 years of amphibian chytridiomycosis research. Ecol Evol 2, 4079-4097 (2015).

8. D. H. Olson et al., Mapping the global emergence of Batrachochytrium dendrobatidis, the amphibian chytrid fungus. PLOS ONE 8, doi.org/10.1371/journal.pone.0056802 (2013).

9. S. N. Stuart et al., Status and trends of amphibian declines and extinctions worldwide. Science 306, 1783-1786 (2004).

10. J. Bielby, N. Cooper, A. A. Cunningham, T. W. J. Garner, A. Purvis, Predicting susceptibility to future declines in the world's frogs. Conserv. Lett. 1, 82-90 (2008).

11. K. R. Lips, J. D. Reeve, L. R. Witters, Ecological traits predicting amphibian population declines in Central America. Conserv. Biol. 17, 1078-1088 (2003).

12. The IUCN Red List of Threatened Species, Version 2017-3. (IUCN Species Survival Commission, Gland, Switzerland, http://www.iucnredlist.org).

13. T. S. Doherty, A. S. Glen, D. G. Nimmo, E. G. Ritchie, C. R. Dickman, Invasive predators and global biodiversity loss. Proc. Natl. Acad. Sci. USA 113, 11261-11265 (2016). 
14. W. E. Thogmartin et al., White-nose syndrome is likely to extirpate the endangered Indiana bat over large parts of its range. Biol. Conserv. 160, 162-172 (2013).

15. T. L. George et al., Persistent impacts of West Nile virus on North American bird populations. Proc. Natl. Acad. Sci. USA 112, 14290-14294 (2015).

16. E. La Marca et al., Catastrophic population declines and extinctions in neotropical harlequin frogs (Bufonidae: Atelopus). Biotropica 37, 190-201 (2005).

17. D. J. Gower et al., Batrachochytrium dendrobatidis infection and lethal chytridiomycosis in caecilian amphibians (Gymnophiona). EcoHealth 10, 173-183 (2013).

18. J. Voyles et al., Shifts in disease dynamics in a tropical amphibian assemblage are not due to pathogen attenuation. Science 359, 1517-1519 (2018).

19. A. Valenzuela-Sánchez et al., Cryptic disease-induced mortality may cause host extinction in an apparently stable host-parasite system. Proc. R. Soc. B 284, 20171176 (2017).

20. D. B. Wake, V. T. Vredenburg, Are we in the midst of the sixth mass extinction? A view from the world of amphibians. Proc. Natl. Acad. Sci. USA 105, 11466-11473 (2008).

21. J. E. Houlahan, C. S. Findlay, B. R. Schmidt, A. H. Meyer, S. L. Kuzmin, Quantitative evidence for global amphibian population declines. Nature 404, 752-755 (2000).

22. B. L. Talley, C. R. Muletz, V. T. Vredenburg, R. C. Fleischer, K. R. Lips, A century of Batrachochytrium dendrobatidis in Illinois amphibians (1888-1989). Biol. Conserv. 182, 254-261 (2015).

23. D. B. Wake, Declining amphibian populations. Science 253, 860-860 (1991).

24. K. R. Lips, J. Diffendorfer, J. R. Mendelson III, M. W. Sears, Riding the wave: Reconciling the roles of disease and climate change in amphibian declines. PLoS Biol. 6 , 441-454 (2008).

25. A. Catenazzi, E. Lehr, L. O. Rodriguez, V. T. Vredenburg, Batrachochytrium dendrobatidis and the collapse of anuran species richness and abundance in the Upper Manu National Park, southeastern Peru. Conserv. Biol. 25, 382-391 (2011).

26. C. Morrison, J. M. Hero, Geographic variation in life-history characteristics of amphibians: a review. J. Anim. Ecol. 72, 270-279 (2003).

30 27. R. A. Knapp et al., Large-scale recovery of an endangered amphibian despite ongoing exposure to multiple stressors. Proc. Natl. Acad. Sci. USA 113, 11889-11894 (2016). 
28. A. K. Wiethoelter, D. Beltrán-Alcrudo, R. Kock, S. M. Mor, Global trends in infectious diseases at the wildlife-livestock interface. Proc. Natl. Acad. Sci. USA 112, 9662-9667 (2015).

29. K. J. Olival et al., Host and viral traits predict zoonotic spillover from mammals. Nature 546, 646-650 (2017).

30. T. W. Garner et al., Mitigating amphibian chytridiomycoses in nature. Phil. Trans. R. Soc. B 371, 20160207 (2016).

31. J. E. Longcore, A. P. Pessier, D. K. Nichols, Batrochochytrium dendrobatidis gen. et sp. nov., a chytrid pathogenic to amphibians Mycologia 91, 219-227 (1999).

32. B. C. Scheele et al., After the epidemic: Ongoing declines, stabilizations and recoveries in amphibians afflicted by chytridiomycosis. Biol. Conserv. 206, 37-46 (2017).

33. I. Dohoo, S. Martin, H. Stryhn, Veterinary Epidemiologic Research. (Charlottetown, Canada, ed. 2nd, 2009).

34. A. J. Crawford, K. R. Lips, E. Bermingham, Epidemic disease decimates amphibian abundance, species diversity, and evolutionary history in the highlands of central Panama. Proc. Natl. Acad. Sci. USA 107, 13777-13782 (2010).

35. The IUCN Red List of Threatened Species, Version 2016-1. (IUCN Species Survival Commission, Gland, Switzerland, http://www.iucnredlist.org).

36. A. Purvis, J. L. Gittleman, G. Cowlishaw, G. M. Mace, Predicting extinction risk in declining species. Proc. R. Soc. Lond., Ser. B: Biol. Sci. 267, 1947-1952 (2000).

37. K. A. Murray, D. Rosauer, H. McCallum, L. F. Skerratt, Integrating species traits with extrinsic threats: closing the gap between predicting and preventing species declines. Proc. R. Soc. Lond., Ser. B: Biol. Sci. 278, 1515-1523 (2011).

38. K. A. Murray et al., Assessing spatial patterns of disease risk to biodiversity: implications for the management of the amphibian pathogen, Batrachochytrium dendrobatidis. $J$. Appl. Ecol. 48, 163-173 (2011).

39. R. Puschendorf et al., Distribution models for the amphibian chytrid Batrachochytrium dendrobatidis in Costa Rica: proposing climatic refuges as a conservation tool. Divers. Distrib. 15, 401-408 (2009).

40. M. Plummer, in Proceedings of the 3rd International Workshop on Distributed Statistical Computing (DSC 2003). (Vienna, Austria, 2005). 
41. S. E. Fick, R. J. Hijmans, WorldClim 2: new 1-km spatial resolution climate surfaces for global land areas. Int. J. Climatol. 37, 4302-4315 (2017).

42. B. F. Oliveira, V. A. São-Pedro, G. Santos-Barrera, C. Penone, G. C. Costa, AmphiBIO, a global database for amphibian ecological traits. Sci. Data 4, sdata2017123 (2017).

43. K. M. Kriger, J. M. Hero, The chytrid fungus Batrachochytrium dendrobatidis is nonrandomly distributed across amphibian breeding habitats. Divers. Distrib. 13, 781-788 (2007).

44. Amphibiaweb. (University of California, Berkeley, CA, USA. 2017).

45. S. N. Stuart et al., Threatened Amphibians of the World. (Lynx Edicions, Barcelona, Spain; IUCN, Gland, Switzerland; Conservation International, Arlington, Virginia, USA, 2008).

46. J. J. L. Rowley, R. A. Alford, Hot bodies protect amphibians against chytrid infection in nature. Sci. Rep. 3, e1515 (2013).

47. C. L. Richards-Zawacki, Thermoregulatory behaviour affects prevalence of chytrid fungal infection in a wild population of Panamanian golden frogs. Proc. R. Soc. Lond., Ser. B: Biol. Sci. 277, 519-528 (2010). 


\section{Acknowledgments:}

We thank M. Arellano, E. Courtois, A. Cunningham, K. Murray, S. Ron, R. Puschendorf, J. Rowley and V. Vredenburg for discussions on amphibian declines. Comments from two anonymous reviewers greatly improved the manuscript. Funding: B.C.S. and D.B.L. were supported by the Australian National Environmental Science Program. L.B., L.F.S., T.A.K. and B.C.S. were supported by the Australian Research Council (grants FT100100375, LP110200240, DP120100811), the NSW Office of Environment and Heritage and the Taronga Conservation Science Initiative. S.C., W.B., A.M. and F.P. were supported by the grants FWO3E001916, FWO11ZK916N-11ZK918N and BOF16/GOA/024. S.C. was supported by grant FWO16/PDO/019. A.A.A. was supported by the Conservation Leadership Program (0621310) and Colciencias (1121-659-44242). T.C. was supported by the Coordination for the Improvement of Higher Education Personnel. A.C. was supported by the Amazon Conservation Association, the Amphibian Specialist Group, the Disney Worldwide Conservation Fund, the Eppley Foundation, the Mohammed bin Zayed Species Conservation Fund, the NSF, the Rufford Small Grants Foundation and the Swiss National Foundation. I.D.1.R. was supported by the Spanish Government (CGL2014-56160-P). M.C.F. was supported by the NERC (NE/K014455/1), the Leverhulme Trust (RPG-2014-273) and the Morris Animal Foundation (D16ZO-022). S.V.F. was supported by the USFWS Wildlife without Borders (96200-0-G228), the AZA Conservation Endowment Fund (08-836) and the Conservation International Critically Endangered Species Fund. P.F.A. was supported by a Postdoctoral Research fellowship from the Mexican Research Council (CONACYT, 171465). T.W.J.G. was supported by the NERC (NE/N009967/1 and NE/K012509/1). J.M.G. was supported by the Universidad San Francisco de Quito (Collaboration grants 11164, 5447). M.H. was supported by scholarships from the Elsa- 
Neumann-Foundation and the German Academic Exchange Service (DAAD). C.A.M. was supported by the Atkinson Center for a Sustainable Future and the Cornell Center for Vertebrate Genomics. G.P.O. was supported by DGAPA-UNAM and CONACYT while on sabbatical at the University of Otago, New Zealand. C.L.R-Z. was supported by the NSF (1660311). S.M.R. was supported by CONACYT Problemas Nacionales grant (PDCPN 2015-721) and a UC MexusConacy cooperative grant. C.S-A. was supported by the Chilean National Science and Technology Fund (Fondecyt Nº1181758). L.F.T. was supported by the São Paulo Research Foundation (FAPESP \#2016/25358-3) and the National Council for Scientific and Technological Development (CNPq \#300896/2016-6). J.V. was supported by the NSF (DEB-1551488, IOS1603808). C.W. was supported by the South African National Research Foundation. Author contributions: B.C.S., F.P., L.B., L.F.S., A.M., and S.C. conceived the research. B.C.S. collated the data/coordinated data collection. All authors contributed ideas and data. S.C. conducted the analysis, with input from B.C.S., F.P., A.M., C.N.F. and W.B.. B.C.S., F.P., L.B., L.F.S., A.M., C.N.F., and S.C. wrote the paper with input from all authors. Competing interests: Authors declare no competing interests. Data and materials availability: All data are available in the manuscript or the supplementary material.

\section{Supplementary Materials:}

Materials and Methods

Figure S1. Timing of declines by geographic area.

Figure S2. Multiplicative effect sizes of predictors of decline severity and recovery.

Table S1. Summary of modelling results for the timing of species declines.

Table S2. Summary of modelling results for predictors of decline severity. 
Table S3. Summary of modelling results for predictors of recovery.

Table S4. Complete legend of taxonomic groups as indicated in Figure 2 (main text).

Data S1 (Excel format)

References (31-47) 

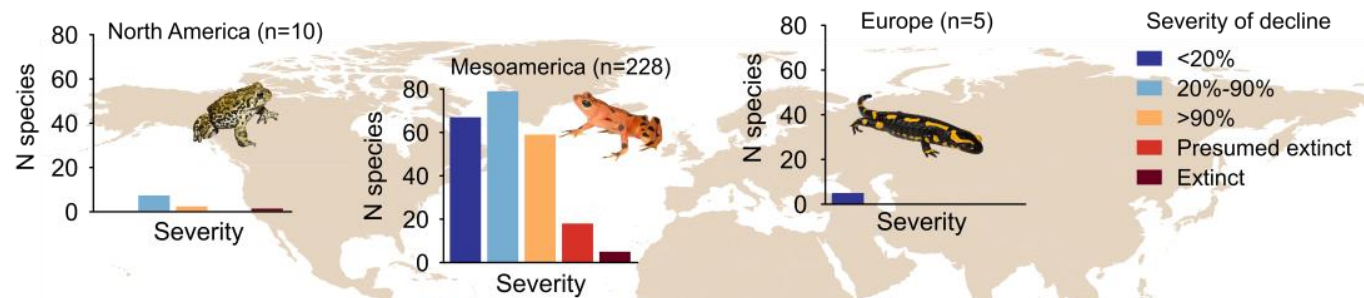$$
\text { - Presumed extinct }
$$$$
\text { - Extinct }
$$
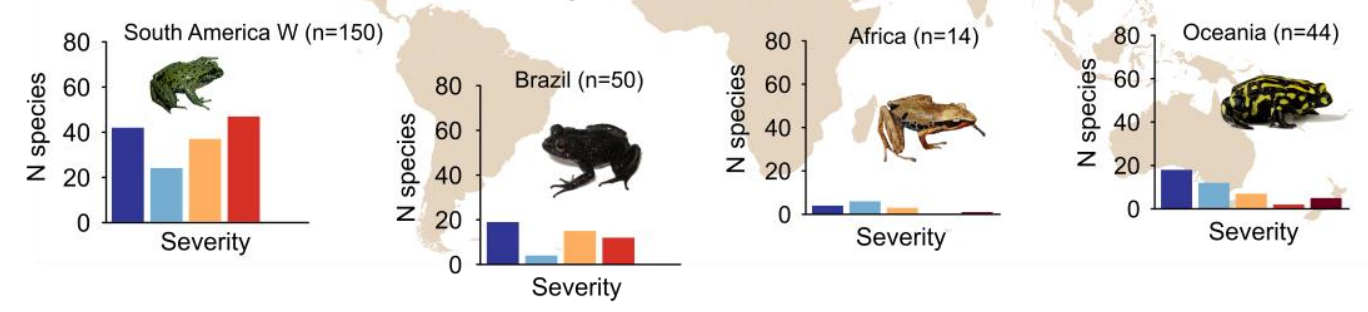

\section{Fig. 1. Global distribution of chytridiomycosis-associated amphibian species declines. Bar} plots indicate the number of declined species, grouped by continental area and classified by decline severity. Brazilian species are plotted separately from all other South American species (South America W); Mesoamerica includes Central America, Mexico and the Caribbean Islands; Oceania includes Australia and New Zealand. No declines have been reported in Asia. [Photo credits (left to right): Anaxyrus boreas, Chris Brown; Telmatobius sanborni, Ignacio De la Riva; Atelopus varius, Brian Gratwicke; Cycloramphus boraceiensis, L. F. Toledo; Cardioglossa melanogaster, Mareike Hirschfeld; Salamandra salamandra, Didier Descouens; Pseudophryne corroboree, Corey Doughty]. 


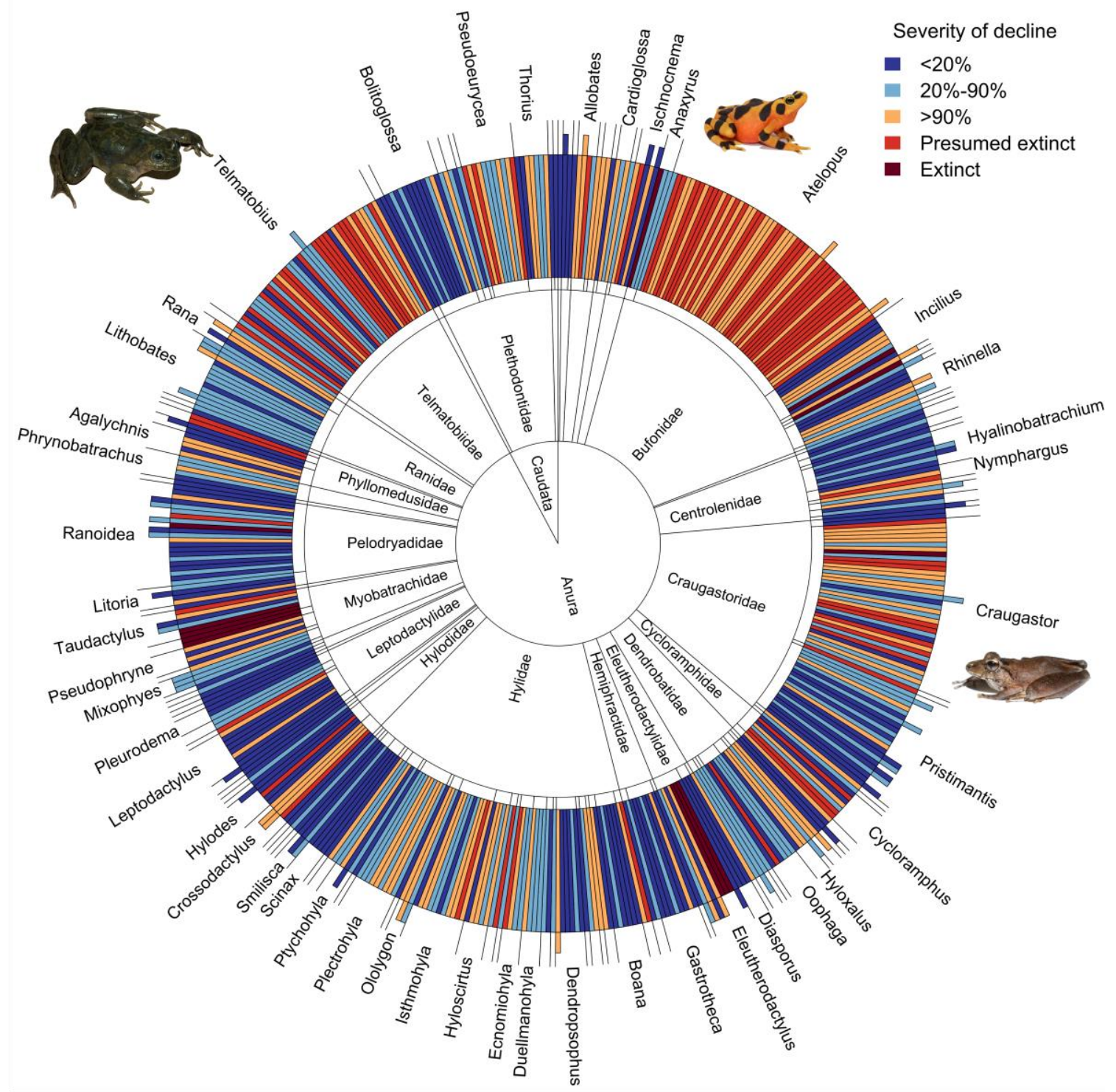

Fig. 2. Taxonomic distribution of chytridiomycosis-associated amphibian declines. Each bar represents one species, color denotes the severity of its decline. Concentric circles indicate, from inner to outer, order (Caudata or Anura), family and genus. Full names given only for families and genera including $>5$ and $>2$ species respectively; details for all taxa in table S4. Within each taxonomic level, sublevels are ordered alphabetically. Protruding bars indicate species for which there is evidence of recovery. [Photo credits (left to right): Telmatobius bolivianus, Ignacio De la Riva; Atelopus zeteki and Craugastor crassidigitus, Brian Gratwicke]. 

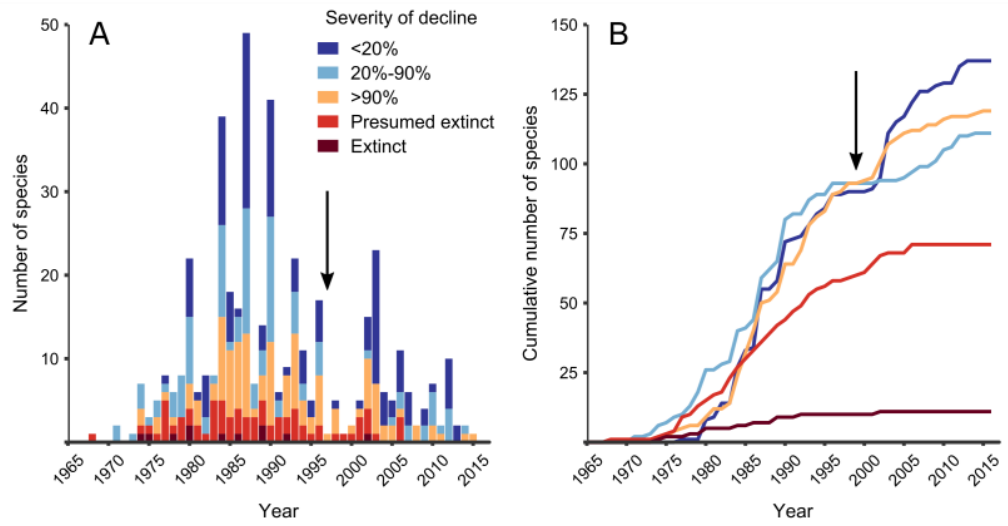

Fig. 3. Timing of chytridiomycosis-associated amphibian declines. In (A), bars indicate the cumulative number of declines in a given year, stacked by decline severity. For species in which the exact year of decline is uncertain, the figure shows the middle year of the interval of uncertainty, as stated by experts or inferred from available data. In (B), curves indicate the cumulative number of declines in each decline severity category in time. Arrows mark the discovery of chytridiomycosis in 1998. 


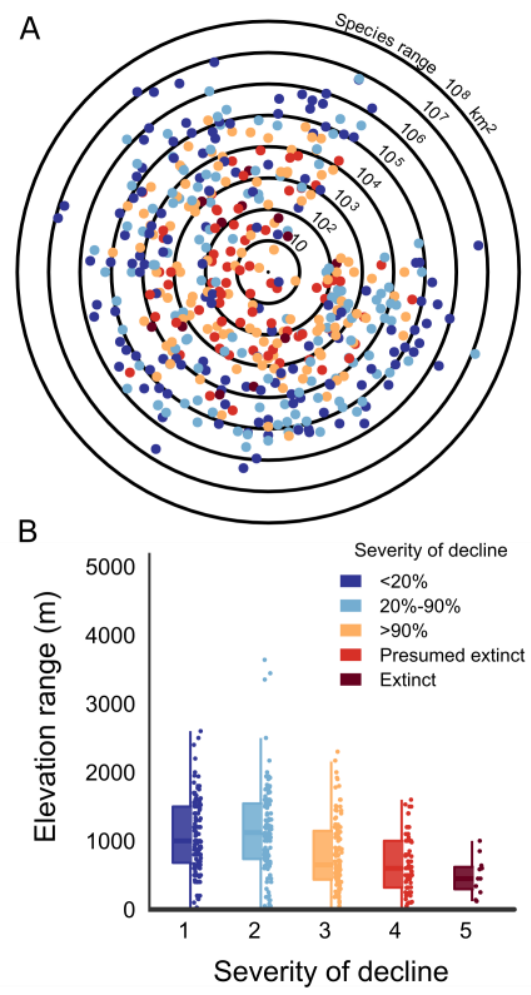

Fig. 4. Severity of chytridiomycosis-associated amphibian declines in relation to the geographic (A) and elevational (B) range of species. In (A) each dot indicates a species, located randomly along the perimeter of a circle with radius equal to the $\log ^{10}$ of the species' geographic range in $\mathrm{km}^{2}$. In (B), horizontal bars, boxes and vertical bars indicate, respectively, mean, first and second quartiles, and $95 \%$ quantiles of elevation ranges within each category of decline severity. 


\section{Science MIAAAS}

\section{Supplementary Materials for}

\section{Amphibian fungal panzootic causes catastrophic and ongoing loss of}

\section{biodiversity}

Authors: Ben C. Scheele ${ }^{1,2,3^{*}}$, Frank Pasmans ${ }^{4}$, Lee F. Skerratt ${ }^{3}$, Lee Berger $^{3}$, An Martel ${ }^{4}$, Wouter Beukema ${ }^{4}$, Aldemar A. Acevedo ${ }^{5,6}$, Patricia A. Burrowes ${ }^{7}$, Tamilie Carvalho ${ }^{8}$, Alessandro Catenazzi ${ }^{9}$, Ignacio De la Riva ${ }^{10}$, Matthew C. Fisher ${ }^{11}$, Sandra V. Flechas ${ }^{12,13}$, Claire N. Foster ${ }^{1}$, Patricia Frías-Álvarez ${ }^{3}$, Trenton W. J. Garner ${ }^{14}$, Brian Gratwicke $^{15}$, Juan M. Guayasamin ${ }^{16,17,18}$, Mareike Hirschfeld ${ }^{19}$, Jonathan E. Kolby ${ }^{3,20,21}$, Tiffany A. Kosch ${ }^{3}$, Enrique La Marca $^{22}$, David B. Lindenmayer ${ }^{1,2 D}$, Karen R. Lips ${ }^{23}$, Ana V. Longo ${ }^{23}$, Raul Maneyro ${ }^{24}$, Cait A. McDonald ${ }^{25}$, Joseph Mendelson III ${ }^{26,27}$, Pablo Palacios-Rodriguez ${ }^{12}$, Gabriela Parra-Olea ${ }^{28}$, Corinne L. Richards-Zawacki ${ }^{29}$, Mark-Oliver Rödel ${ }^{19}$, Sean M. Rovito ${ }^{30}$, Claudio Soto-Azat ${ }^{31}$, Luís Felipe Toledo ${ }^{8}$, Jamie Voyles ${ }^{32}$, Ché Weldon ${ }^{33}$,

*Correspondence author: ben.scheele@ @anu.edu.au (B.C.S.) 


\section{This PDF file includes:}

Materials and Methods

Figure S1. Timing of species declines by geographic area.

Figure S2. Multiplicative effect sizes for predictors of severity and recovery.

Table S1. Summary of modelling results for the timing of species declines.

Table S2. Summary of modelling results for predictors of decline severity.

Table S3. Summary of modelling results for predictors of recovery from declines.

Table S4. Complete legend of taxonomic groups as indicated in Figure 2 (main text).

Data S1 (Excel format) 


\section{Materials and Methods}

\section{Compilation of declined-species dataset}

Chytridiomycosis and amphibian declines

Chytridiomycosis is a lethal disease of amphibians that was discovered in 1998 (1). In amphibians, chytridiomycosis can develop from infection with one of two fungal species, Batrachochytrium dendrobatidis (described in 1999, 2) or B. salamandrivorans (described in 2013, 3). We identified chytridiomycosis-associated declines caused by infection with either $B$. dendrobatidis or B. salamandrivorans. We found evidence for the decline of only one amphibian

10 species (Salamandra salamandra) associated with infection with $B$. salamandrivorans, and subsequently for convenience in the following Supplementary Materials, we focus on chytridiomycosis-associated declines resulting from infection with $B$. dendrobatidis.

Two previous efforts have attempted to quantify the number of amphibian species that have experienced declines associated with chytridiomycosis. First, the International Union for the Conservation of Nature (IUCN) Global Amphibian Assessment (GAA), conducted from 2001 to 2004, concluded that 202 amphibian species had experienced "enigmatic" declines, but did not directly attribute these declines to chytridiomycosis (4). However, the GAA was conducted when knowledge of chytridiomycosis and its impacts on amphibians was rudimentary. Building on the GAA, Skerratt et al. (5) used multiple lines of evidence to argue that $B$. dendrobatidis was the agent driving "enigmatic" declines identified in the GAA.

Since the 2001-2004 GAA, B. dendrobatidis has continued to spread into new regions (6) and understanding of chytridiomycosis and its impacts on amphibian hosts has greatly increased. For example, a search for "Batrachochytrium dendrobatidis" yields 40 results on the 
Web of Science from 2004 and earlier, but 1,258 results for 2005-2017. However, despite these advances, the scale and number of global amphibian declines associated with chytridiomycosis has yet to be empirically quantified, or examined in light of major developments in our understanding of this disease.

Identifying declined species

We developed an expert-curated list of species that have experienced declines associated with chytridiomycosis (a method analogous with the IUCN approach to evaluating conservation status). We used a two-step process to identify declined species. First, at a continental scale, we searched for evidence of amphibian declines associated with chytridiomycosis. This involved searching the scientific literature and discussions with amphibian experts. Second, if chytridiomycosis-associated declines were identified for a particular continent, we then engaged regional amphibian experts, generally at the country level, to thoroughly compile information on all chytridiomycosis-associated amphibian declines, using the framework and methods described below. Regional experts were chosen based on their professional experience in amphibian ecology in the region, and knowledge of chytridiomycosis. In the case of Asia, there was no evidence for chytridiomycosis-associated declines, and as such, further assessments of amphibians from that continent were not conducted. We acknowledge that this approach could fail to identify some very recent or only locally known declines. However, such cases are unlikely to substantially affect our analyses as existing knowledge would likely be insufficient to determine the role of chytridiomycosis in the decline.

Our focus was on identifying species that had experienced declines due to chytridiomycosis (as specified below), rather than on identifying species in which infection with 
either B. dendrobatidis or B. salamandrivorans has been documented. This is an important distinction, as some amphibian species can be infected with either pathogen, but not experience morbidity or mortality (asymptomatic) or population declines $(7,8)$. The global database $B$. dendrobatidis-maps [http://www.bd-maps.net] provides information on species in which infections have been documented.

For the second step of our assessment conducted in 2017, we assembled a team of 41 researchers with expertise in both amphibian ecology and chytridiomycosis to undertake country-level assessments for 24 countries where there was evidence that chytridiomycosis has contributed to amphibian declines. Following the methodology of Scheele et al. (9), for each species, experts collated all available peer-reviewed articles, government technical reports, theses, conference proceedings, books, information from IUCN assessments, and unpublished data on species' status and trends recorded by amphibian ecologists. The scientific literature was searched through Google Scholar and ISI Web of Knowledge. Bibliographies of relevant papers were checked to identify further literature. Relevant information and sources underpinning the inclusion of each declined species in the dataset is provided in data S1. Prior to commencing their assessments, each expert thoroughly discussed the assessment methodology with the lead author (B.C.S.) to ensure consistent interpretation and implementation of the assessment framework.

As initial outbreaks of chytridiomycosis occurred in many regions before its discovery, and many impacted amphibian species are difficult to observe and/or occur in remote habitats, quantifying the role of chytridiomycosis in declines is, for many species, challenging and retrospective. As such, we developed an epidemiological framework (see Metadata tab in data S1) to integrate all available evidence (including laboratory, experimental and field data) to 
evaluate the severity, distribution, and timing of amphibian declines caused by chytridiomycosis. This approach of incorporating multiple lines of evidence is commonly used in health disciplines (10), has previously been applied to a continent-wide assessment of chytridiomycosis-associated declines (9), and uses published criteria (5) for determining disease causation in population declines.

We identified species that had undergone declines in abundance caused by chytridiomycosis. We define decline severity as the total estimated reduction (\%) in abundance across a species' range, associated with chytridiomycosis. Most of the assessed species have undergone declines in both abundance and range. However, we elected to focus on changes in abundance because, in the context of chytridiomycosis, declines in abundance and range are often conflated due to environmental context influencing disease impacts, with range reductions cumulating from population extinctions driven by reductions in abundance.

Our quantification of $B$. dendrobatidis-associated declines is likely conservative for three main reasons. First, B. dendrobatidis has likely caused the decline of many undescribed species, a phenomenon that might be particularly relevant in the Neotropics where there are many undescribed species (11). Second, species may have declined due to chytridiomycosis, but there is currently no evidence linking their decline to the disease. In such cases, these species have not been included in our assessment. Third, the true extent of a species' decline associated with $B$. dendrobatidis may be unrecognized. As such, species may be categorized in a less severe decline category because, while there is evidence for the role of $B$. dendrobatidis in the species' decline in parts of its range, declines in other parts of its range have not (yet) been attributed to $B$. dendrobatidis. In addition, declines could be under-documented in species with large ranges, due to logistical challenges associated with monitoring and surveying widely distributed species.

Declined species were grouped into five broad classes of severity: (1) minor decline $<20 \%$ in abundance; (2) severe decline $>20 \%$ but $<90 \%$; (3) extreme decline $>90 \%$; (4) 
presumed extinct in the wild (no known extant populations, and no individuals detected at known historical locations, but some reasonable doubt that the last individual has died); and (5) confirmed extinct in the wild (as per IUCN listing). Note that the class "Extinct" includes both "Extinct" and "Extinct in the Wild" sensu IUCN. For each declined species, we also assessed whether there was evidence for ongoing population declines due to chytridiomycosis (i.e. populations experiencing continued declines following the initial emergence of chytridiomycosis) (yes, no, unknown, not applicable [for presumed or confirmed extinct species]), and whether partial recovery of declined species had been observed (yes, no, unknown, not applicable [for presumed or confirmed extinct species]). Species were classified as experiencing ongoing decline if chytridiomycosis was causing continuing reductions in abundance after initial declines associated with chytridiomycosis outbreaks. Species were classified as experiencing partial recovery if increases in abundance were reported after initial declines caused by chytridiomycosis outbreaks. We report the year recovery commenced for populations of species subject to regular surveys. For species where signs of recovery have been reported, but the absence of regular surveys prevent identification of when recoveries commenced, we provide the first year that recoveries were reported. No date is provided when precise information is unavailable. We note that a high degree of caution is needed in interpreting information on species recovery. In many cases, declined species have only shown signs of recovery in some populations, and in general still have greatly reduced abundance compared with historical levels. Detailed examples of how declines were categorized for eight species with varying decline severities are provided in the 'Worked_examples' worksheet in data S1. 
Timing of species declines

Species were assigned either a year of decline commencement $(n=104)$, or if this was not known, an uncertainty interval during which the decline was thought to have occurred $(\mathrm{n}=$ 345). If known, experts provided the year that decline commenced. If the year was unknown, experts estimated a range of years during which the decline could have occurred, or provided a year which could be indirectly related to the timing of decline (e.g. the last year the species was observed as abundant, or the first year that observations were made of populations post-decline (12). In such cases, we represented uncertainty by defining an interval of years. Intervals were either provided directly by experts, or where experts provided only a start- or end-year for decline, we conservatively assumed a ten-year interval, respectively, before or after the stated year. For some Mesoamerican species (particularly in Panama), rather than an interval, the contributors provided temporal information about the first detection of $B$. dendrobatidis in different areas of the region, and based on that information, we inferred the period during which decline might have occurred as a five-year interval on both sides of the first known detection of B. dendrobatidis within the range of the species, based on the IUCN distribution maps (13). In total, information about the timing of declines was available for 449 species out of 501 in our dataset. Species for which no data about the timing of declines were available $(n=52)$ were excluded from later statistical models (Timing of declines and Predictors of declines and recoveries below). In those models, each species was assigned a single year of decline, to avoid overrepresentation of species with longer uncertainty intervals. For species with a two- or threeyear interval, we used the first and middle year respectively. Where the uncertainty interval of the timing of decline was longer than three years, we drew a random year within that interval to avoid systematic bias towards the beginning, mid- or endpoints of the interval. 
Evidence for the role of chytridiomycosis in species declines

For each declined species, assessors evaluated the following: 1) Was B. dendrobatidis diagnosed using histopathology and/or PCR to confirm infection during mass die-offs or sudden declines? 2) Did declines coincide with the documented emergence and spread of $B$. dendrobatidis in the region? 3) Is the declined species highly susceptible to $B$. dendrobatidis in laboratory experiments (i.e. $>75 \%$ individuals die post exposure in the laboratory) or demographic field studies? 4) Did sympatric species decline simultaneously due to $B$. dendrobatidis? For each question, species were assigned 'yes', 'no', or 'no data'. The strength of evidence linking $B$. dendrobatidis to each species decline was then scored from one to four, with four being the strongest evidence of $B$. dendrobatidis-associated declines. One = expert opinion of the assessor only. Two $=$ single line of correlative evidence. Three $=$ multiples lines of correlative evidence. Four = robust before-after decline sampling demonstrating declines were caused by $B$. dendrobatidis.

\section{$\underline{\text { Statistical analyses }}$}

We used generalized linear models to assess the temporal trend in the overall number of declines, in the severity of those declines, and in the probability of a species' recovery. We also sought to identify attributes of species distributions (e.g. range size, climatic region, elevation) and life-history traits that were associated with decline severity and recovery. We selected these variables based on previous work on extinction risk in vertebrates (14), life-history traits previously linked to chytridiomycosis-associated declines (15-17), as well as known bioclimatic preference of $B$. dendrobatidis $(7,18,19)$. All models described below were fit in JAGS (20), 
using uninformative priors for all parameters, and run for 150,000 iterations on three Markov chains, with a burn-in of 75,000 and a thinning rate of 10 . Convergence was assessed by visual inspection of the chain histories and using the $R$-hat statistic.

First, we modelled the temporal trend in the overall number of declines. As outlined above, we associated each species with a year of decline (as explained in section 'Timing of species declines' above). For each year between 1970 (the earliest year in our dataset) and 2016, we counted the number of species that had that year as the stated or inferred year of decline and used this as a Poisson-distributed response variable, with year of decline as a predictor.

We compared three alternative functions: null (constant number, i.e. no temporal trend), linear (constant increasing or decreasing trend in the number of declines) and quadratic (to reflect an initial increase, followed by a decrease in the number of declines). Given the simple structure of the models, we compared models on the basis of the coefficient estimates and discarded terms for which the $95 \%$ credible interval of the posterior distribution of the regression coefficient encompassed zero (analogous to failure to reject the null hypothesis with $\alpha=0.05$ if working with a null hypothesis significance test). Results are summarized in table S1.

We also modelled the severity of individual declines as a function of time. Because severity was a categorical variable, ordered from 1 to 5 , we used a multinomial logit link regression with year of decline, defined as above, as a predictor (moderator). The output of the model can be interpreted as the probability that a species falls in a given severity class. Consequently, a positive coefficient for time (year) would indicate that species with later declines were more likely to suffer more severe impacts. To account for the varying degree of 
evidence supporting the decline of each species, we took an approach analogous to a metaanalysis (21). We defined the prior variance of the linear estimator for the multinomial probability of a species falling in a higher severity class as a function of the corresponding amount of evidence $(1,10,100$ and 1000 for the four levels of evidence from highest to lowestsee Evidence for the role of chytridiomycosis in species declines). We added a random effect to account for taxonomic autocorrelation (using the genus of each species as a blocking factor, nested within its family).

We also modelled species recovery (yes/no) using logistic regression and year of decline as a predictor, following the same procedure as above. Here, a negative regression coefficient would suggest species with earlier declines were more likely to have recovered (as expected if there was a time lag between decline and recovery). We excluded species from this analysis if they had gone extinct or if there was no data on population trajectory after the initial decline, leading to a final set of 254 species (including 60 known recoveries).

Finally, visual analysis of the dataset also led us to hypothesize that declines (particularly less severe ones) may have been under-reported or supported by less evidence before 1975 . Therefore, we repeated all analyses described below selecting only those species for which the exact or inferred year of decline was 1975 or later. All results were confirmed with and without pre-1975 data.

Predictors of declines and recoveries

We sought to identify factors that explained the severity of declines and the probability of species recovery. With severity of decline (1 to 5) and recovery (yes/no) as the respective response variables, we used the same model formulations as above, respectively, multinomial 
and logistic regression. For severity of impact, we again used the level of evidence to weigh the prior variance of the linear predictor. For both analyses, we again added a random effect at the genus and family level to account for taxonomic autocorrelation.

We began the analysis for severity with a full model that included 10 covariates, selected on the basis of data availability, hypotheses about host and pathogen ecology, and preliminary visual analysis of the data (see next paragraph for detailed descriptions). The 10 covariates were: (1) Geographic range, expressed as the $\log _{10}$ of the extent of the species range in $\mathrm{km}^{2}$; (2) Latitude, calculated as the absolute value for the centroid of the species' distribution; (3) Mean elevation across the species range (included because it is associated with a range of factors that may either affect suitability for $B$. dendrobatidis, such as temperature and precipitation, or host characteristics that may affect vulnerability to declines, such as lower connectivity in high elevation species and increased age to maturity (22); (4) Elevational range, expressed as the $\log _{10}$ of the difference between the maximum and minimum elevations across the species' range; (5) Body size, expressed as the $\log _{10}$ of the mean snout-to-vent length for the species; (6) Clutch size, expressed as the $\log _{10}$ of the average number of eggs/offspring for the species; (7) Three variables describing association with aquatic habitat: use of aquatic habitat ( 1 if adults of the species use aquatic habitats for at least part of the year, 0 for species fully terrestrial as adults), association with permanent water bodies, and direct development (note that because these three variables were highly correlated with each other (Pearson's $r>0.5$, see below), only one was included in the model at a time); (8) Activity pattern of the species ( 0 for nocturnal species, 1 for all other species not strictly nocturnal); (9) Maximum temperature of the warmest month, averaged over the species range from BIOCLIM05 variable (23); and (10) Precipitation of the driest quarter of the year, averaged over the species range from the BIOCLIM17 variable (23). 
Another 20 additional variables potentially associated with chytridiomycosis were discarded after preliminary modelling and visual analysis (clear absence of visual patterns when plotted, large credible intervals for regression coefficients centered close to zero), leaving the 10 listed above as the set we analysed in detail. These discarded variables included environmental specialization, expressed as the number of environments (arid, temperate, sub-tropical, tropical, sub-alpine, alpine) where the species is known to occur, habitat topography, additional reproductive modes such as use of bromeliads, lakes, wetlands or terrestrial clutches, all BIOCLIM variables other than $\mathrm{BIO} 05$ and $\mathrm{BIO} 17$, including maximum and minimum annual temperature and precipitation as well as seasonality patterns. The final set of 10 variables covered a wide range of ecological hypotheses about chytridiomycosis-related declines (see below).

Species distribution maps were obtained from the IUCN Red List of Threatened Species (24), from which the geographical range was calculated in ArcGIS 10.1. Minimum and maximum elevations used to acquire elevational ranges (with median elevation calculated as the midpoint) were obtained from species-specific online IUCN Red List accounts. Body size and clutch size were extracted from the AmphiBIO database (25) and were included to reflect life history strategies. Data about association with aquatic habitat were provided by contributors of our dataset and were included to reflect the previously demonstrated link between $B$. dendrobatidis-driven declines and aquatic habitats $(15,26)$; activity patterns of the species were compiled from AmphibiaWeb (27) and Stuart et al. (28), and were included due to the thermoregulatory behavior of some species that can inhibit B. dendrobatidis growth $(29,30)$. Finally, averaged temperature and precipitation data spanning each species' range were obtained from the corresponding BIOCLIM variables of the WorldClim 2 dataset (23) at 30 arc second 
$( \pm 1 \times 1 \mathrm{~km})$ resolution, calculated across the IUCN Red List distribution maps in ArcGIS 10.1. We chose the BIOCLIM05 and 17 variables to reflect whether, within a species range, part of the year was especially unsuitable for $B$. dendrobatidis persistence and growth, due to a marked dry and/or warm season. We also evaluated interaction terms between environmental (BIOCLIM) and elevation/range covariates. Finally, we added to the initial model a covariate for year of decline where the previous analysis (see above) suggested a significant relationship between time of decline and severity/recovery. For recovery, given the smaller initial dataset, we fitted the initial model with a subset of these variables, following the rule of thumb of at least ten observations in the less represented class (recovery yes/no) for each predictor, and assessing all possible combinations of covariates within that constraint. Because species that have experienced very large declines are unlikely to recover for demographic reasons, we excluded from the analysis all species known or presumed extinct, for which recovery would be impossible by definition, and included an additional predictor to reflect such small-population bottlenecks ( 0 if the species suffered a decline $>90 \%$, and 1 otherwise). This allowed us to account for demographic barriers to recovery, and identify environmental and life history correlates of recovery among species that may have remained unaffected by such barriers.

Preliminary analysis confirmed that correlation between pairs of predictors did not exceed $r=0.5$, except for the three variables describing association with aquatic habitat, of which only one at a time was included in models. In particular, we noted that median elevation and elevational range of species had a Pearson's correlation of $r=0.01$, allowing the inclusion of both variables in the models. We centered all continuous variables by subtracting their mean to improve convergence. Rather than using complex imputation techniques, for each combination of covariates we removed species for which values of at least one covariate were missing. We fit 
the model in JAGS using the settings and convergence diagnostics described above. We then progressively simplified the model by removing covariates for which the $95 \%$ credible interval of the posterior distribution of the regression coefficient encompassed zero (analogous to failure to reject the null hypothesis with $\alpha=0.05$ if working with a null hypothesis significance test). As a covariate was dropped from the model, we added back to the data set any species that had been removed because they missed a value for that covariate, after confirming there was no taxonomic or geographic bias in species that were added at a later stage. When two or more covariates had to be removed, we removed one at a time, beginning from the covariate with the smallest available sample size. Because the three variables describing association with aquatic habitat were highly correlated, only one was included in the model at a time, so we repeated the entire process for each of them. For decline severity and recovery, respectively, the full models contained 102 and 84 species (mostly reflecting limited information about body size and clutch size). As explained above, in the multinomial logistic regression for severity of decline, a positive coefficient for a given covariate would indicate that species with higher values of that covariate (e.g. larger body size) were more likely to be classified in a higher severity class. In the logistic regression for recovery, a positive coefficient would indicate that species with higher values of that covariate were more likely to have recovered from the decline. Results are summarized in tables S2-S3.

We also evaluated the realized effect of each covariate on the response variable, calculating the multiplicative effect size $E$ of covariate $i$ as the product of the corresponding estimated regression coefficient $\beta$ by the range of that covariate in the dataset: $E_{i}=$ $e^{\beta_{i}\left(\max _{i}-\min _{i}\right)}$. Multiplicative effect sizes indicate how much the odds of the response variable (i.e. being classified in a higher severity of decline or having recovered from decline) increase or 
decrease across the observed range of the covariate: values greater and smaller than one indicate positive and negative effects respectively, while a value of one suggests no effect. Figure S2

illustrates the cumulative effect sizes for all predictors for decline severity (fig. S2 A) and recovery (fig. S2 B). 

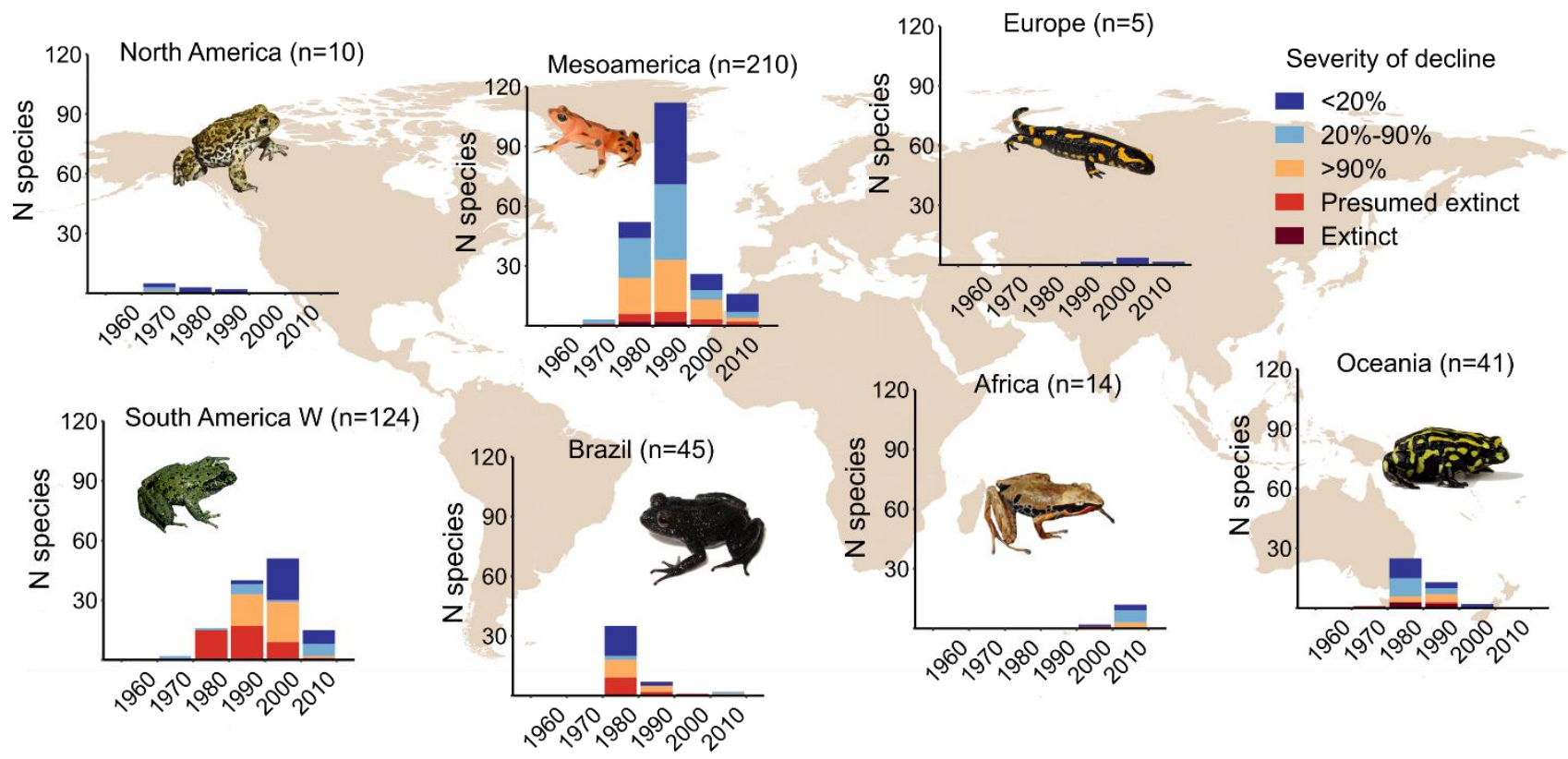

Figure S1. Timing of species declines by geographic area. Bars indicate the number of declines in a given decade, stacked by decline severity. For species in which the exact year of decline is uncertain, the figure uses the middle year of the interval of uncertainty, as stated by experts or inferred from available data. Brazilian species are plotted separately from all other South American species (South America W); Mesoamerica includes Central America, Mexico and the Caribbean Islands; Oceania includes Australia and New Zealand. No declines have been reported in Asia. [Photo credits (left to right): Anaxyrus boreas, Chris Brown; Telmatobius sanborni, Ignacio De la Riva; Atelopus varius, Brian Gratwicke; Cycloramphus boraceiensis, L. F. Toledo; Cardioglossa melanogaster, Mareike Hirschfeld; Salamandra salamandra, Didier Descouens; Pseudophryne corroboree, Corey Doughty]. 

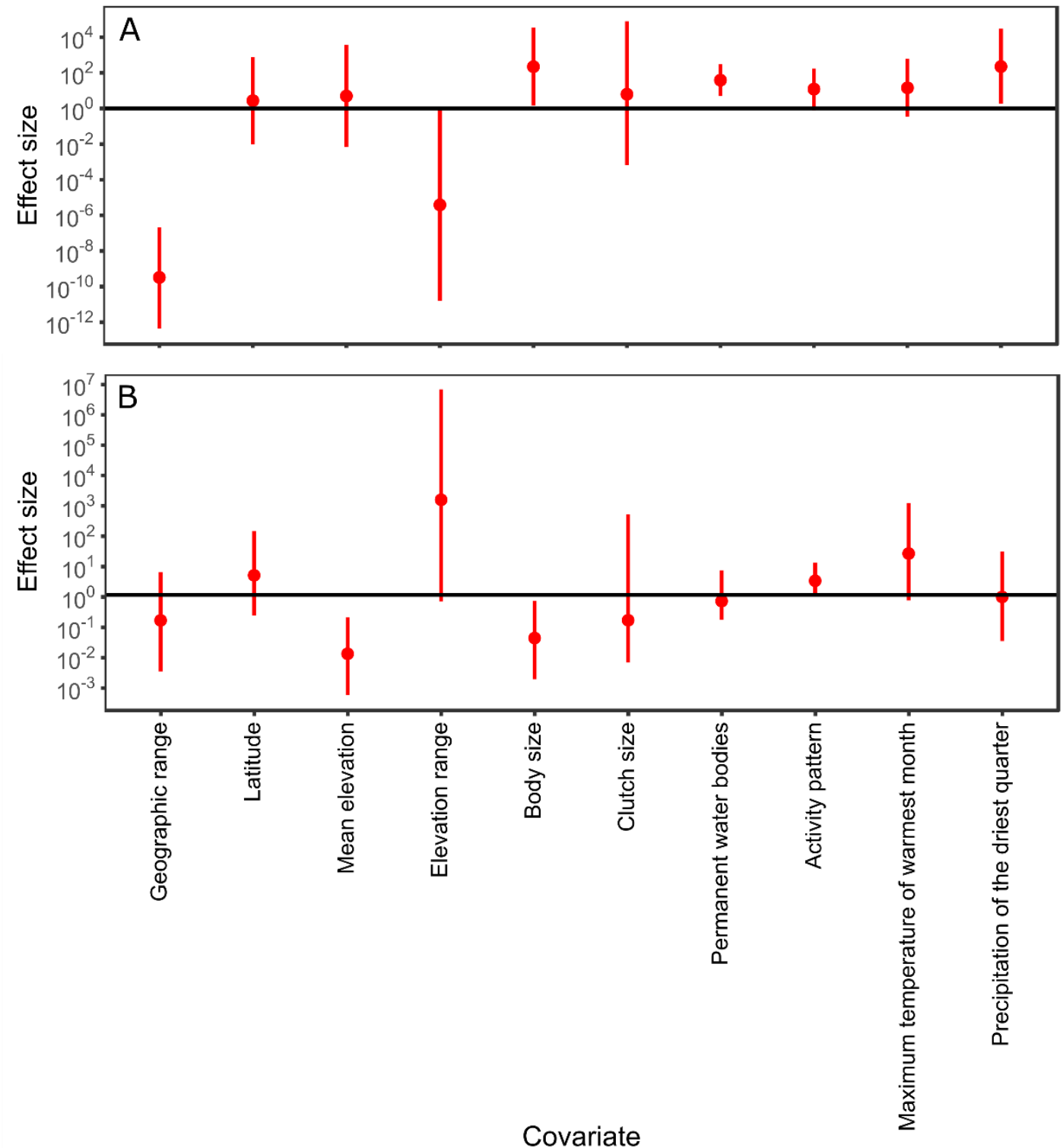

Figure S2. Multiplicative effect sizes for predictors of (A) decline severity and (B) recovery. Values greater and smaller than one indicate positive and negative effects respectively; a value of one (horizontal line) suggests no effect. Values are calculated from the ranges and coefficients in tables S2 and S3. Bars indicate 95\% credible intervals. 
Table S1. Summary of modelling results for the timing of species declines. Estimates refer to the mean estimate of the regression coefficients for each model, respectively, intercept $\alpha$, linear term $\beta_{\text {time }}$ and quadratic term $\beta_{\text {time2 }}(95 \%$ credible intervals in parentheses). "Retained" refers to whether the variable was retained as significantly influencing the severity of declines (when the 95\% credible interval of the regression coefficient's posterior distribution did not encompass zero).

\begin{tabular}{|c|c|c|}
\hline Model & $\underline{\text { Mean } \underline{\beta}} \underline{(95 \%} \underline{\text { CRI })}$ & Retained \\
\hline \multicolumn{3}{|c|}{ Total number of declines $(n=449)$} \\
\hline Decline $\sim$ & $\alpha=2.25(2.16,2.34)$ & No \\
\hline Decline $\sim$ time & $\begin{array}{l}\alpha=2.53(2.35,2.71) \\
\beta_{\text {time }}=-1.13(-1.84,-0.41)\end{array}$ & No \\
\hline Decline $\sim$ time $^{2}$ & $\begin{array}{l}\alpha=1.28(0.94,1.59) \\
\beta_{\text {time }}=14.37(11.33,17.51) \\
\beta_{\text {time } 2}=-34.88(-41.86,28.19)\end{array}$ & Yes \\
\hline \multicolumn{3}{|c|}{ Severity of decline $(n=449)$} \\
\hline Severity $\sim$. & $\alpha=-1.46(-7.08,3.79)$ & No \\
\hline Severity $\sim$ time & $\begin{array}{l}\alpha=-1.32(-6.08,4.02) \\
\beta_{\text {time }}=-9.65(-15.36,-3.96)\end{array}$ & Yes \\
\hline Severity $\sim$ time $^{2}$ & $\begin{array}{l}\alpha=-0.17(-6.04,4.75) \\
\beta_{\text {time }}=-9.04(-18.37,0.31) \\
\beta_{\text {time2 }}=-0.84(-17.46,15.68)\end{array}$ & No \\
\hline \multicolumn{3}{|c|}{ Recovery $(n=254)$} \\
\hline
\end{tabular}




\begin{tabular}{|l|l|l|}
\hline Recovery $\sim$ & $\alpha=-1.86(-3.05,-0.92)$ & No \\
\hline Recovery $\sim$ time & $\alpha=-0.86(-2.15,0.33)$ & Yes \\
& $\beta_{\text {time }}=-5.45(-10.14,-1.04)$ & \\
\hline Recovery $\sim$ time ${ }^{2}$ & $\alpha=-1.13(-2.52,0.15)$ & No \\
& $\beta_{\text {time }}=-1.85(-10.12,6.19)$ & \\
& $\beta_{\text {time } 2}=-8.49(-24.56,7.55)$ & \\
\hline
\end{tabular}


Table S2. Summary of results for predictors of the severity of species declines. "Range" refers to the range of a variable in the largest analysed dataset (all continuous variables were centred and modelled on the $\log _{10}$ scale). " $\beta$ " refers to the mean estimate of the regression coefficient for each variable (95\% credible intervals in parentheses). "Sample size" refers to the size of the largest fitted dataset which included the variable. "Retained" refers to whether the variable was retained as significantly influencing the severity of declines (when the $95 \%$ credible interval of the regression coefficient's posterior distribution did not encompass zero).

\begin{tabular}{|l|l|l|l|l|}
\hline Variable & Range $\left(\log _{10}\right)$ & Mean $\beta(95 \%$ CRI) & Sample size & Retained \\
\hline Geographic range $\left(\mathrm{km}^{2}\right)$ & $-5.04,3.36$ & $-2.60(-3.39,-1.83)$ & 297 & Yes \\
\hline Latitude & $-1.58,0.62$ & $0.46(-2.12,3.01)$ & 217 & No \\
\hline Mean elevation (m asl) & $-1.24,0.61$ & $0.87(-2.69,4.46)$ & 217 & No \\
\hline Elevation range (m) & $-4.84,0.70$ & $-2.25(-4.49,-0.03)$ & 297 & Yes \\
\hline Body size (SVL in mm) & $-0.55,0.77$ & $4.09(0.28,7.93)$ & 297 & Yes \\
\hline $\begin{array}{l}\text { Clutch size (n) } \\
\text { Permanent water bodies } \\
\text { (yes/no) }\end{array}$ & $-1.50,1.97$ & $0.53(-2.10,3.25)$ & 102 & No \\
\hline $\begin{array}{l}\text { Activity pattern } \\
\text { (strictly nocturnal yes/no) }\end{array}$ & 0,1 & $3.66(1.64,5.72)$ & 297 & Yes \\
\hline
\end{tabular}




\begin{tabular}{|l|l|l|l|l|}
\hline $\begin{array}{l}\text { Maximum temperature of } \\
\text { warmest month (C) }\end{array}$ & $-0.27,0.15$ & $6.35(-2.55,15.26)$ & 297 & No \\
\hline $\begin{array}{l}\text { Precipitation of the driest } \\
\text { quarter (mm) }\end{array}$ & $-1.26,0.88$ & $2.53(0.28,4.81)$ & 297 & Yes \\
\hline
\end{tabular}


Table S3. Summary of results for predictors of species recovery (yes/no). "Range" refers to the range of a variable in the largest analysed dataset (all continuous variables were centred and modelled on the $\log _{10}$ scale). " $\beta$ " refers to the regression coefficient for the variable (on the $\log _{10}$ scale for continuous variables). "Sample size" refers to the size of the largest fitted dataset which included the variable (number of known recoveries in parentheses). "Retained" refers to whether the variable was retained as significantly influencing the probability of recovery.

\begin{tabular}{|l|l|l|l|l|}
\hline Variable & Range & Mean $\beta(95 \%$ CRI) & Sample size & Retained \\
\hline Geographic range $\left(\mathrm{km}^{2}\right)$ & $-11.86,7.47$ & $-0.10(-0.30,0.09)$ & $209(50)$ & No \\
\hline Latitude & $-1.60,0.62$ & $0.67(-0.70,2.18)$ & $210(48)$ & No \\
\hline Mean elevation (m asl) & $-1.06,0.49$ & $-2.59(-4.82,-0.53)$ & $164(41)$ & Yes \\
\hline Elevation range (m) & $-2.89,0.83$ & $1.94(-0.13,4.19)$ & $164(41)$ & No \\
\hline Body size (SVL in mm) & $-0.46,0.77$ & $-2.92(-5.39,-0.67)$ & $164(41)$ & Yes \\
\hline Clutch size (n) & $-1.52,1.85$ & $-0.57(-1.52,1.81)$ & $84(28)$ & No \\
\hline $\begin{array}{l}\text { Permanent water bodies } \\
\text { (yes/no) }\end{array}$ & 0,1 & $-0.47(-0.87,1.87)$ & $164(41)$ & No \\
\hline $\begin{array}{l}\text { Activity pattern } \\
\text { (strictly nocturnal yes/no) }\end{array}$ & 0,1 & $1.07(0.05,2.46)$ & $154(37)$ & Yes \\
\hline $\begin{array}{l}\text { Maximum temperature of } \\
\text { warmest month (C) }\end{array}$ & $-0.27,0.15$ & $7.66(-1.01,16.98)$ & $158(40)$ & No \\
\hline
\end{tabular}




\begin{tabular}{|l|l|l|l|l|}
\hline Precipitation of the driest & $-1.30,0.87$ & $-0.07(-1.61,1.52)$ & $158(40)$ & No \\
quarter $(\mathrm{mm})$ & & & & \\
\hline
\end{tabular}


Table S4. Complete legend of taxonomic groups as indicated in Figure 2 (main text).

\begin{tabular}{|c|c|c|c|c|c|}
\hline Order & Family & Genus & Species & Severity & Recovery \\
\hline \multirow[t]{40}{*}{ Anura } & Alsodidae & Alsodes & Alsodes tumultuosus & & no \\
\hline & Alytidae & Alytes & Alytes muletensis & & yes \\
\hline & & & Alytes obstetricans & & unknown \\
\hline & & Discoglossus & Discoglossus sardus & & unknown \\
\hline & Aromobatidae & Allobates & Allobates alessandroi & & 3 no \\
\hline & & & Allobates capixaba* & & 3 yes \\
\hline & & & Allobates olfersioides & & n/a \\
\hline & & & Allobates talamancae & & unknown \\
\hline & & Aromobates & Aromobates meridensis & & 3 no \\
\hline & & Mannophryne & Mannophryne collaris & & 3 no \\
\hline & & & Mannophryne cordilleriana & & 3 no \\
\hline & Arthroleptidae & Arthroleptis & Arthroleptis variabilis & & no \\
\hline & & Cardioglossa & Cardioglossa manengouba & & 3 no \\
\hline & & & Cardioglossa pulchra & & no \\
\hline & & & Cardioglossa trifasciata & & 3 no \\
\hline & Brachycephalidae & Brachycephalus & Brachycephalus alipioi & & 2 no \\
\hline & & Ischnocnema & Ischnocnema epipeda & & 3 no \\
\hline & & & Ischnocnema paranaensis & & $\mathrm{n} / \mathrm{a}$ \\
\hline & & & Ischnocnema parva & & yes \\
\hline & & & Ischnocnema pusilla & & 3 no \\
\hline & & & Ischnocnema sp. aff. guentheri & & yes \\
\hline & Bufonidae & Anaxyrus & Anaxyrus baxteri & & $\mathrm{n} / \mathrm{a}$ \\
\hline & & & Anaxyrus boreas & & no \\
\hline & & & Anaxyrus canorus & & 2 no \\
\hline & & Atelopus & Atelopus andinus & & unknown \\
\hline & & & Atelopus angelito & & $\mathrm{n} / \mathrm{a}$ \\
\hline & & & Atelopus arthuri & & $4 \mathrm{n} / \mathrm{a}$ \\
\hline & & & Atelopus balios & & 3 no \\
\hline & & & Atelopus bomolochos & & 3 no \\
\hline & & & Atelopus boulengeri & & $\mathrm{n} / \mathrm{a}$ \\
\hline & & & Atelopus carbonerensis & & n/a \\
\hline & & & Atelopus certus & & 3 no \\
\hline & & & Atelopus chiriquiensis & & $\mathrm{n} / \mathrm{a}$ \\
\hline & & & Atelopus chrysocorallus & & n/a \\
\hline & & & Atelopus coynei & & $\mathrm{n} / \mathrm{a}$ \\
\hline & & & Atelopus cruciger & & 3 unknown \\
\hline & & & Atelopus dimorphus & & $\mathrm{n} / \mathrm{a}$ \\
\hline & & & Atelopus elegans & & 3 no \\
\hline & & & Atelopus epikeisthos & & $\mathrm{n} / \mathrm{a}$ \\
\hline & & & Atelopus erythropus & & 3 no \\
\hline
\end{tabular}




\begin{tabular}{|c|c|c|c|c|c|}
\hline Order & Family & Genus & Species & Severity & Recovery \\
\hline & & & Atelopus eusebiodiazi & & $\mathrm{n} / \mathrm{a}$ \\
\hline & & & Atelopus exiguus & & 3 no \\
\hline & & & Atelopus glyphus & & no \\
\hline & & & Atelopus gиапијо & & $\mathrm{n} / \mathrm{a}$ \\
\hline & & & Atelopus halihelos & & $\mathrm{n} / \mathrm{a}$ \\
\hline & & & Atelopus ignescens & & 3 no \\
\hline & & & Atelopus limosus & & 3 no \\
\hline & & & Atelopus longirostris & & no \\
\hline & & & Atelopus lynchi & & $\mathrm{n} / \mathrm{a}$ \\
\hline & & & Atelopus mindoensis & & $\mathrm{n} / \mathrm{a}$ \\
\hline & & & Atelopus mucubajiensis & & no \\
\hline & & & Atelopus nanay & & no \\
\hline & & & Atelopus nepiozomus & & 3 no \\
\hline & & & Atelopus onorei & & $\mathrm{n} / \mathrm{a}$ \\
\hline & & & Atelopus orcesi & & $\mathrm{n} / \mathrm{a}$ \\
\hline & & & Atelopus oxyrhynchus & & $\mathrm{n} / \mathrm{a}$ \\
\hline & & & Atelopus pachydermus & & no \\
\hline & & & Atelopus palmatus & & no \\
\hline & & & Atelopus pastuso & & $\mathrm{n} / \mathrm{a}$ \\
\hline & & & Atelopus patazensis & & yes \\
\hline & & & Atelopus peruensis & & $\mathrm{n} / \mathrm{a}$ \\
\hline & & & Atelopus petersi & & $n / a$ \\
\hline & & & Atelopus pinangoi & & $\mathrm{n} / \mathrm{a}$ \\
\hline & & & Atelopus planispina & & $\mathrm{n} / \mathrm{a}$ \\
\hline & & & Atelopus podocarpus & & $\mathrm{n} / \mathrm{a}$ \\
\hline & & & Atelopus pulcher & & no \\
\hline & & & Atelopus pyrodactylus & & $\mathrm{n} / \mathrm{a}$ \\
\hline & & & Atelopus reticulatus & & $\mathrm{n} / \mathrm{a}$ \\
\hline & & & Atelopus senex & & $\mathrm{n} / \mathrm{a}$ \\
\hline & & & Atelopus sorianoi & & $\mathrm{n} / \mathrm{a}$ \\
\hline & & & Atelopus sp. & & $\mathrm{n} / \mathrm{a}$ \\
\hline & & & Atelopus spurrelli & & unknown \\
\hline & & & Atelopus tamaense & & $\mathrm{n} / \mathrm{a}$ \\
\hline & & & Atelopus tricolor & & no \\
\hline & & & Atelopus varius & & yes \\
\hline & & & Atelopus zeteki & & $\mathrm{n} / \mathrm{a}$ \\
\hline & & Incilius & Incilius aucoinae & & unknown \\
\hline & & & Incilius coniferus & & unknown \\
\hline & & & Incilius epioticus & & unknown \\
\hline & & & Incilius fastidiosus & & no \\
\hline & & & Incilius holdridgei & & no \\
\hline & & & Incilius ibarrai & & 3 no \\
\hline
\end{tabular}




\begin{tabular}{|c|c|c|c|c|c|}
\hline Order & Family & Genus & Species & Severity & Recovery \\
\hline & & & Incilius macrocristatus & & no \\
\hline & & & Incilius periglenes & & $\mathrm{n} / \mathrm{a}$ \\
\hline & & & Incilius signifer & & unknown \\
\hline & & Melanophryniscus & Melanophryniscus moreirae & & yes \\
\hline & & Nectophrynoides & Nectophrynoides asperginis & & $\mathrm{n} / \mathrm{a}$ \\
\hline & & Rhaebo & Rhaebo haematiticus & & yes \\
\hline & & Rhinella & Rhinella alata & & unknown \\
\hline & & & Rhinella arunco & & no \\
\hline & & & Rhinella centralis & & unknown \\
\hline & & & Rhinella leptoscelis & & yes \\
\hline & & & Rhinella quechua & & no \\
\hline & & & Rhinella spinulosa & & yes \\
\hline & & & Rhinella veraguensis & & no \\
\hline & & Werneria & Werneria tandyi & & no \\
\hline & Calyptocephale & Calyptocephalella & Calyptocephalella gayi & & no \\
\hline & Centrolenidae & Centrolene & Centrolene buckleyi & & unknown \\
\hline & & & Centrolene daidaleum & & no \\
\hline & & Cochranella & Cochranella euknemos & & no \\
\hline & & & Cochranella granulosa & & no \\
\hline & & Espadarana & Espadarana prosoblepon & & unknown \\
\hline & & Hyalinobatrachium & Hyalinobatrachium aureoguttatum & & unknown \\
\hline & & & Hyalinobatrachium bergeri & & no \\
\hline & & & Hyalinobatrachium chirripoi & & unknown \\
\hline & & & Hyalinobatrachium colymbiphyllum & & yes \\
\hline & & & Hyalinobatrachium fleischmanni & & yes \\
\hline & & & Hyalinobatrachium talamancae & & unknown \\
\hline & & Hyalinobatrachium & Hyalinobatrachium valerioi & & unknown \\
\hline & & Nymphargus & Nymphargus griffithsi & & no \\
\hline & & & Nymphargus pluvialis & & no \\
\hline & & & Nymphargus truebae & & $\mathrm{n} / \mathrm{a}$ \\
\hline & & Rulyrana & Rulyrana spiculata & & no \\
\hline & & Sachatamia & Sachatamia albomaculata & & yes \\
\hline & & & Sachatamia ilex & & unknown \\
\hline & & Teratohyla & Teratohyla pulverata & & unknown \\
\hline & & & Teratohyla spinosa & & unknown \\
\hline & & Vitreorana & Vitreorana eurygnatha & & yes \\
\hline & Craugastoridae & Bryophryne & Bryophryne cophites & & no \\
\hline & & & Bryophryne zonalis & & unknown \\
\hline & & Craugastor & Craugastor anciano & & $\mathrm{n} / \mathrm{a}$ \\
\hline & & & Craugastor andi & & no \\
\hline & & & Craugastor angelicus & & 3 no \\
\hline
\end{tabular}




\begin{tabular}{|c|c|c|c|c|c|}
\hline Order & Family & Genus & Species & Severity & Recovery \\
\hline & & & Craugastor aurilegulus & & 3 no \\
\hline & & & Craugastor azueroensis & & 3 unknown \\
\hline & & & Craugastor bransfordii & & 2 unknown \\
\hline & & & Craugastor catalinae & & 3 no \\
\hline & & & Craugastor chrysozetetes & & $5 \mathrm{n} / \mathrm{a}$ \\
\hline & & & Craugastor crassidigitus & & 2 unknown \\
\hline & & & Craugastor cruzi & & $4 \mathrm{n} / \mathrm{a}$ \\
\hline & & & Craugastor emleni & & $4 \mathrm{n} / \mathrm{a}$ \\
\hline & & & Craugastor escoces & & 3 unknown \\
\hline & & & Craugastor evanesco & & 3 no \\
\hline & & & Craugastor fitzingeri & & 2 unknown \\
\hline & & & Craugastor fleischmanni & & 3 no \\
\hline & & & Craugastor gollmeri & & 3 unknown \\
\hline & & & Craugastor megacephalus & & 2 yes \\
\hline & & & Craugastor melanostictus & & 1 unknown \\
\hline & & & Craugastor mexicanus & & 2 no \\
\hline & & & Craugastor milesi & & 3 no \\
\hline & & & Craugastor monnichorum & & 2 unknown \\
\hline & & & Craugastor noblei & & 3 unknown \\
\hline & & & Craugastor obesus & & $4 \mathrm{n} / \mathrm{a}$ \\
\hline & & & Craugastor omoaensis & & $4 \mathrm{n} / \mathrm{a}$ \\
\hline & & & Craugastor opimus & & 2 unknown \\
\hline & & & Craugastor podiciferus & & 1 unknown \\
\hline & & & Craugastor punctariolus & & $4 \mathrm{n} / \mathrm{a}$ \\
\hline & & & Craugastor ranoides & & 3 no \\
\hline & & & Craugastor rhyacobatrachus & & $4 \mathrm{n} / \mathrm{a}$ \\
\hline & & & Craugastor rugosus & & 2 unknown \\
\hline & & & Craugastor stadelmani & & $4 \mathrm{n} / \mathrm{a}$ \\
\hline & & & Craugastor stejnegerianus & & 1 unknown \\
\hline & & & Craugastor tabasarae & & 3 no \\
\hline & & & Craugastor talamancae & & 2 unknown \\
\hline & & & Craugastor taurus & & 3 no \\
\hline & & & Craugastor underwoodi & & 2 unknown \\
\hline & & Holoaden & Holoaden bradei & & $4 \mathrm{n} / \mathrm{a}$ \\
\hline & & Pristimantis & Pristimantis anolirex & & 2 no \\
\hline & & & Pristimantis caryophyllaceus & & 2 yes \\
\hline & & & Pristimantis cerasinus & & 2 unknown \\
\hline & & & Pristimantis cosnipatae & & 3 unknown \\
\hline & & & Pristimantis cruentus & & 2 unknown \\
\hline & & & Pristimantis danae & & 1 unknown \\
\hline & & & Pristimantis gaigei & & 2 yes \\
\hline & & & Pristimantis gracilis & & 1 no \\
\hline
\end{tabular}




\begin{tabular}{|c|c|c|c|c|c|}
\hline Order & Family & Genus & Species & Severity & Recovery \\
\hline & & & Pristimantis gryllus & & no \\
\hline & & & Pristimantis melanoproctus & & 2 no \\
\hline & & & Pristimantis mondolfii & & no \\
\hline & & & Pristimantis moro & & 2 unknown \\
\hline & & & Pristimantis museosus & & 3 unknown \\
\hline & & & Pristimantis nicefori & & no \\
\hline & & & Pristimantis palmeri & & yes \\
\hline & & & Pristimantis pardalis & & 2 yes \\
\hline & & & Pristimantis pharangobates & & unknown \\
\hline & & & Pristimantis platydactylus & & yes \\
\hline & & & Pristimantis ridens & & 2 yes \\
\hline & & & Pristimantis salaputium & & unknown \\
\hline & & & Pristimantis taeniatus & & unknown \\
\hline & & & Pristimantis toftae & & yes \\
\hline & & Strabomantis & Strabomantis bufoniformis & & 3 no \\
\hline & & Tachiramantis & Tachiramantis douglasi & & 2 no \\
\hline & \multirow[t]{9}{*}{ Cycloramphidae } & Cycloramphus & Cycloramphus boraceiensis & & no \\
\hline & & & Cycloramphus duseni & & $4 \mathrm{n} / \mathrm{a}$ \\
\hline & & & Cycloramphus fuliginosus & & no \\
\hline & & & Cycloramphus granulosus & & 3 no \\
\hline & & & Cycloramphus semipalmatus & & 2 no \\
\hline & & & Cycloramphus stejnegeri & & $4 \mathrm{n} / \mathrm{a}$ \\
\hline & & & Cycloramphus valae & & $4 \mathrm{n} / \mathrm{a}$ \\
\hline & & Thoropa & Thoropa petropolitana & & 3 no \\
\hline & & & Thoropa taophora & & no \\
\hline & \multirow[t]{16}{*}{ Dendrobatidae } & Ameerega & Ameerega flavopicta & & yes \\
\hline & & Andinobates & Andinobates minutus & & unknown \\
\hline & & Colostethus & Colostethus panamansis & & 3 yes \\
\hline & & & Colostethus pratti & & 3 no \\
\hline & & Dendrobates & Dendrobates auratus & & 2 yes \\
\hline & & Hyloxalus & Hyloxalus abditaurantius & & 3 no \\
\hline & & & Hyloxalus fascianigrus & & 3 no \\
\hline & & & Hyloxalus lehmanni & & no \\
\hline & & Oophaga & Oophaga arborea & & 2 unknown \\
\hline & & & Oophaga granulifera & & 2 unknown \\
\hline & & & Oophaga histrionica & & 2 no \\
\hline & & & Oophaga pumilio & & unknown \\
\hline & & & Oophaga speciosa & & $4 \mathrm{n} / \mathrm{a}$ \\
\hline & & & Oophaga vicentei & & unknown \\
\hline & & Phyllobates & Phyllobates lugubris & & 2 unknown \\
\hline & & Ranitomeya & Ranitomeya claudiae & & 2 unknown \\
\hline
\end{tabular}




\begin{tabular}{|c|c|c|c|c|c|}
\hline Order & Family & Genus & Species & Severity & Recovery \\
\hline & & Silverstoneia & Silverstoneia flotator & & 2 yes \\
\hline & & & Silverstoneia nubicola & & 2 unknown \\
\hline & \multirow[t]{12}{*}{ Eleutherodactylidae } & Adelophryne & Adelophryne baturitensis & & 3 no \\
\hline & & Diasporus & Diasporus diastema & & 1 unknown \\
\hline & & & Diasporus hylaeformis & & 1 unknown \\
\hline & & & Diasporus quidditus & & 1 unknown \\
\hline & & Eleutherodactylus & Eleutherodactylus coqui & & 1 yes \\
\hline & & & Eleutherodactylus eneidae & & $5 \mathrm{n} / \mathrm{a}$ \\
\hline & & & Eleutherodactylus jasperi & & $5 \mathrm{n} / \mathrm{a}$ \\
\hline & & & Eleutherodactylus karlschmidti & & $5 \mathrm{n} / \mathrm{a}$ \\
\hline & & & Eleutherodactylus locustus & & 3 yes \\
\hline & & & Eleutherodactylus portoricensis & & 1 yes \\
\hline & & & Eleutherodactylus richmondi & & 3 yes \\
\hline & & & Eleutherodactylus wightmanae & & 2 yes \\
\hline & \multirow[t]{11}{*}{ Hemiphractidae } & Fritziana & Fritziana ohausi & & 1 no \\
\hline & & Gastrotheca & Gastrotheca antoniiochoai & & 1 unknown \\
\hline & & & Gastrotheca cornuta & & 3 no \\
\hline & & & Gastrotheca dendronastes & & 1 no \\
\hline & & & Gastrotheca excubitor & & 1 no \\
\hline & & & Gastrotheca helenae & & 2 no \\
\hline & & & Gastrotheca nebulanastes & & 1 no \\
\hline & & & Gastrotheca nicefori & & 1 no \\
\hline & & & Gastrotheca testudinea & & 1 no \\
\hline & & Hemiphractus & Hemiphractus fasciatus & & 2 unknown \\
\hline & & & Hemiphractus helioi & & 1 no \\
\hline & \multirow[t]{16}{*}{ Hylidae } & Aplastodiscus & Aplastodiscus flumineus & & $4 \mathrm{n} / \mathrm{a}$ \\
\hline & & & Aplastodiscus musicus & & 3 no \\
\hline & & Boana & Boana boans & & 1 unknown \\
\hline & & & Boana gladiator & & 1 unknown \\
\hline & & & Boana pugnax & & 1 unknown \\
\hline & & & Boana rosenbergi & & 1 unknown \\
\hline & & & Boana rufitela & & 2 unknown \\
\hline & & & Boana xerophyla & & 1 no \\
\hline & & Bokermannohyla & Bokermannohyla circumdata & & 1 no \\
\hline & & & Bokermannohyla izecksohni & & 3 no \\
\hline & & Bromeliohyla & Bromeliohyla bromeliaceae & & 3 no \\
\hline & & Charadrahyla & Charadrahyla altipotens & & 3 no \\
\hline & & & Charadrahyla nephila & & 2 no \\
\hline & & Cruziohyla & Cruziohyla calcarifer & & 1 unknown \\
\hline & & Dendropsophus & Dendropsophus ebraccatus & & 1 unknown \\
\hline & & & Dendropsophus meridensis & & 2 no \\
\hline
\end{tabular}




\begin{tabular}{|c|c|c|c|c|}
\hline Order Family & Genus & Species & Severity & Recovery \\
\hline & & Dendropsophus microcephalus & & unknown \\
\hline & & Dendropsophus pelidna & & no \\
\hline & & Dendropsophus phlebodes & & unknown \\
\hline & & Dendropsophus ruschii & & 3 yes \\
\hline & Diaglena & Diaglena spinosa & & 2 unknown \\
\hline & Dryophytes & Dryophytes euphorbiacea & & no \\
\hline & & Dryophytes walkeri & & 2 no \\
\hline & Duellmanohyla & Duellmanohyla ignicolor & & 2 no \\
\hline & & Duellmanohyla schmidtorum & & 2 no \\
\hline & & Duellmanohyla soralia & & 2 no \\
\hline & & Duellmanohyla uranochroa & & 3 no \\
\hline & Ecnomiohyla & Ecnomiohyla echinata & & 2 no \\
\hline & & Ecnomiohyla miliaria & & 2 no \\
\hline & & Ecnomiohyla minera & & 3 no \\
\hline & & Ecnomiohyla rabborum & & $4 \mathrm{n} / \mathrm{a}$ \\
\hline & Exerodonta & Exerodonta melanomma & & 2 no \\
\hline & Hyla & Hyla bocourti & & 4 n/a \\
\hline & & Hyla hazelae & & 2 unknown \\
\hline & Hyloscirtus & Hyloscirtus armatus & & 3 no \\
\hline & & Hyloscirtus colymba & & 2 no \\
\hline & & Hyloscirtus palmeri & & 3 unknown \\
\hline & & Hyloscirtus phyllognathus & & 3 no \\
\hline & & Hyloscirtus platydactylus & & 1 no \\
\hline & Isthmohyla & Isthmohyla angustilineata & & 3 no \\
\hline & & Isthmohyla calypsa & & $4 \mathrm{n} / \mathrm{a}$ \\
\hline & & Isthmohyla debilis & & 3 no \\
\hline & & Isthmohyla graceae & & 3 no \\
\hline & & Isthmohyla lancasteri & & 2 unknown \\
\hline & & Isthmohyla picadoi & & 1 unknown \\
\hline & & Isthmohyla pictipes & & 2 no \\
\hline & & Isthmohyla pseudopuma & & 2 no \\
\hline & & Isthmohyla rivularis & & 3 no \\
\hline & & Isthmohyla tica & & 3 no \\
\hline & & Isthmohyla zeteki & & 1 unknown \\
\hline & Ololygon & Ololygon cf. perpusillus & & 2 yes \\
\hline & & Ololygon heyeri & & 3 yes \\
\hline & & Ololygon peixotoi & & 3 no \\
\hline & Phyllodytes & Phyllodytes luteolus & & 1 no \\
\hline & Plectrohyla & Plectrohyla cyclada & & 2 no \\
\hline & & Plectrohyla dasypus & & 3 no \\
\hline & & Plectrohyla exquisita & & 3 no \\
\hline
\end{tabular}




\begin{tabular}{|c|c|c|c|c|c|}
\hline Order & Family & Genus & Species & Severity & Recovery \\
\hline & & & Plectrohyla hartwegi & & 2 no \\
\hline & & & Plectrohyla ixil & & 3 no \\
\hline & & & Plectrohyla lacertosa & & 3 no \\
\hline & & & Plectrohyla matudai & & 2 no \\
\hline & & & Plectrohyla quecchi & & 2 no \\
\hline & & & Plectrohyla sagorum & & 2 no \\
\hline & & Pseudis & Pseudis paradoxa & & 1 no \\
\hline & & Ptychohyla & Ptychohyla erythromma & & 2 no \\
\hline & & & Ptychohyla hypomykter & & 1 yes \\
\hline & & & Ptychohyla legleri & & 3 no \\
\hline & & & Ptychohyla leonhardschultzei & & 2 no \\
\hline & & Sarcohyla & Sarcohyla arborescandens & & 2 no \\
\hline & & & Sarcohyla sabrina & & 3 no \\
\hline & & Scarthyla & Scarthyla vigilans & & 1 no \\
\hline & & Scinax & Scinax altae & & 1 unknown \\
\hline & & & Scinax boulengeri & & 1 unknown \\
\hline & & & Scinax elaeochrous & & 1 unknown \\
\hline & & & Scinax ruber & & 1 unknown \\
\hline & & Smilisca & Smilisca phaeota & & 2 yes \\
\hline & & & Smilisca sila & & 1 yes \\
\hline & & & Smilisca sordida & & 1 unknown \\
\hline & & Tepuihyla & Tepuihyla edelcae & & 1 no \\
\hline & & Tlalocohyla & Tlalocohyla loquax & & 2 no \\
\hline & & Trachycephalus & Trachycephalus typhonius & & 1 unknown \\
\hline & \multirow[t]{10}{*}{ Hylodidae } & Crossodactylus & Crossodactylus cf. gaudichaudii & & 1 no \\
\hline & & & Crossodactylus dispar & & $4 \mathrm{n} / \mathrm{a}$ \\
\hline & & & Crossodactylus timbuhy & & 3 yes \\
\hline & & & Crossodactylus trachystomus & & 3 yes \\
\hline & & & Crossodactylus werneri & & 3 no \\
\hline & & Hylodes & Hylodes asper & & 1 no \\
\hline & & & Hylodes babax & & 1 no \\
\hline & & & Hylodes glaber & & $4 \mathrm{n} / \mathrm{a}$ \\
\hline & & & Hylodes lateristrigatus & & 1 no \\
\hline & & & Hylodes phyllodes & & 1 yes \\
\hline & \multirow[t]{2}{*}{ Hyperoliidae } & Afrixalus & Afrixalus paradorsalis & & 1 no \\
\hline & & Kassina & Kassina decorata & & 2 no \\
\hline & Leiopelmatidae & Leiopelma & Leiopelma archeyi & & 1 unknown \\
\hline & \multirow[t]{4}{*}{ Leptodactylidae } & Adenomera & Adenomera andreae & & 1 no \\
\hline & & & Adenomera marmorata & & 1 yes \\
\hline & & Leptodactylus & Leptodactylus bolivianus & & 1 unknown \\
\hline & & & Leptodactylus colombiensis & & 1 no \\
\hline
\end{tabular}




\begin{tabular}{|c|c|c|c|c|c|}
\hline Order & Family & Genus & Species & Severity & Recovery \\
\hline & & & Leptodactylus fallax & & no \\
\hline & & & Leptodactylus fragilis & & unknown \\
\hline & & & Leptodactylus melanonotus & & unknown \\
\hline & & & Leptodactylus rhodonotus & & no \\
\hline & & & Leptodactylus savagei & & unknown \\
\hline & & & Leptodactylus sp. & & no \\
\hline & & Paratelmatobius & Paratelmatobius lutzii & & $\mathrm{n} / \mathrm{a}$ \\
\hline & & Physalaemus & Physalaemus henselii & & no \\
\hline & & & Physalaemus jordanensis & & no \\
\hline & & Pleurodema & Pleurodema bibroni & & no \\
\hline & & & Pleurodema brachyops & & unknown \\
\hline & & & Pleurodema marmoratum & & unknown \\
\hline & Limnodynastidae & Adelotus & Adelotus brevis & & no \\
\hline & Microhylidae & Chiasmocleis & Chiasmocleis panamensis & & unknown \\
\hline & & Ctenophryne & Ctenophryne aterrima & & unknown \\
\hline & & Hypopachus & Hypopachus barberi & & no \\
\hline & Myobatrachidae & Geocrinia & Geocrinia victoriana & & no \\
\hline & & Mixophyes & Mixophyes balbus & & yes \\
\hline & & & Mixophyes fleayi & & yes \\
\hline & & & Mixophyes iteratus & & yes \\
\hline & & Philoria & Philoria frosti & & no \\
\hline & & Pseudophryne & Pseudophryne bibronii & & no \\
\hline & & & Pseudophryne corroboree & & no \\
\hline & & & Pseudophryne dendyi & & no \\
\hline & & & Pseudophryne pengilleyi & & no \\
\hline & & Rheobatrachus & Rheobatrachus silus & & $\mathrm{n} / \mathrm{a}$ \\
\hline & & & Rheobatrachus vitellinus & & $\mathrm{n} / \mathrm{a}$ \\
\hline & & Taudactylus & Taudactylus acutirostris & & $\mathrm{n} / \mathrm{a}$ \\
\hline & & & Taudactylus diurnus & & $\mathrm{n} / \mathrm{a}$ \\
\hline & & & Taudactylus eungellensis & & yes \\
\hline & & & Taudactylus liemi & & yes \\
\hline & & & Taudactylus pleione & & no \\
\hline & & & Taudactylus rheophilus & & $\mathrm{n} / \mathrm{a}$ \\
\hline & Odontophrynidae & Proceratophrys & Proceratophrys moratoi & & no \\
\hline & Pelodryadidae & Litoria & Litoria castanea & & no \\
\hline & & & Litoria littlejohni & & no \\
\hline & & & Litoria verreauxii & & yes \\
\hline & & & Litoria verreauxii alpina & & no \\
\hline & & Ranoidea & Ranoidea aurea & & no \\
\hline & & & Ranoidea barringtonensis & & unknown \\
\hline & & & Ranoidea booroolongensis & & no \\
\hline
\end{tabular}




\begin{tabular}{|c|c|c|c|c|c|}
\hline Order & Family & Genus & Species & Severity & Recovery \\
\hline & & & Ranoidea caerulea & & no \\
\hline & & & Ranoidea daviesae & & unknown \\
\hline & & & Ranoidea dayi & & no \\
\hline & & & Ranoidea jungguy & & unknown \\
\hline & & & Ranoidea kroombitensis & & no \\
\hline & & & Ranoidea lesueuri & & unknown \\
\hline & & & Ranoidea lorica & & no \\
\hline & & & Ranoidea nannotis & & yes \\
\hline & & & Ranoidea nudidigita & & yes \\
\hline & & & Ranoidea nyakalensis & & $\mathrm{n} / \mathrm{a}$ \\
\hline & & & Ranoidea pearsoniana & & yes \\
\hline & & & Ranoidea piperata & & $\mathrm{n} / \mathrm{a}$ \\
\hline & & & Ranoidea raniformis & & no \\
\hline & & & Ranoidea rheocola & & yes \\
\hline & & & Ranoidea serrata & & yes \\
\hline & & & Ranoidea spenceri & & no \\
\hline & & & Ranoidea subglandulosa & & unknown \\
\hline & & & Ranoidea wilcoxii & & unknown \\
\hline & Petropedetidae & Petropedetes & Petropedetes perreti & & no \\
\hline & Phrynobatrachidae & Phrynobatrachus & Phrynobatrachus cricogaster & & no \\
\hline & & & Phrynobatrachus jimzimkusi & & no \\
\hline & & & Phrynobatrachus manengoubensis & & no \\
\hline & & & Phrynobatrachus sandersoni & & no \\
\hline & & & Phrynobatrachus werneri & & no \\
\hline & Phyllomedusidae & Agalychnis & Agalychnis annae & & no \\
\hline & & & Agalychnis callidryas & & unknown \\
\hline & & & Agalychnis lemur & & no \\
\hline & & & Agalychnis moreleti & & no \\
\hline & & & Agalychnis spurrelli & & unknown \\
\hline & & Phasmahyla & Phasmahyla exilis & & no \\
\hline & & & Phasmahyla guttata & & yes \\
\hline & & Phrynomedusa & Phrynomedusa bokermanni & & $\mathrm{n} / \mathrm{a}$ \\
\hline & & & Phrynomedusa marginata & & $\mathrm{n} / \mathrm{a}$ \\
\hline & & Phyllomedusa & Phyllomedusa venusta & & unknown \\
\hline & Pipidae & Pipa & Pipa myersi & & unknown \\
\hline & Ranidae & Lithobates & Lithobates chiricahuensis & & no \\
\hline & & & Lithobates maculatus & & yes \\
\hline & & & Lithobates megapoda & & no \\
\hline & & & Lithobates montezumae & & no \\
\hline & & & Lithobates neovolcanicus & & no \\
\hline & & & Lithobates pipiens & & no \\
\hline
\end{tabular}




\begin{tabular}{|c|c|c|c|c|c|}
\hline Order & Family & Genus & Species & Severity & Recovery \\
\hline & & & Lithobates sierramadrensis & & 2 no \\
\hline & & & Lithobates spectabilis & & 2 no \\
\hline & & & Lithobates tarahumarae & & 2 no \\
\hline & & & Lithobates vaillanti & & unknown \\
\hline & & & Lithobates vibicarius & & 3 yes \\
\hline & & & Lithobates warszewitschii & & 2 yes \\
\hline & & & Lithobates yavapaiensis & & 2 yes \\
\hline & & Rana & Rana cascadae & & 2 no \\
\hline & & & Rana maculata & & yes \\
\hline & & & Rana muscosa & & 3 no \\
\hline & & & Rana sierrae & & 3 yes \\
\hline & Rhinodermatidae & Rhinoderma & Rhinoderma darwinii & & 2 no \\
\hline & & & Rhinoderma rufum & & $4 \mathrm{n} / \mathrm{a}$ \\
\hline & Telmatobiidae & Telmatobius & Telmatobius arequipensis & & 2 no \\
\hline & & & Telmatobius atacamensis & & $4 \mathrm{n} / \mathrm{a}$ \\
\hline & & & Telmatobius atahualpai & & unknown \\
\hline & & & Telmatobius bolivianus & & $4 \mathrm{n} / \mathrm{a}$ \\
\hline & & & Telmatobius brevipes & & 2 no \\
\hline & & & Telmatobius brevirostris & & 2 no \\
\hline & & & Telmatobius carrillae & & 2 no \\
\hline & & & Telmatobius ceiorum & & $4 \mathrm{n} / \mathrm{a}$ \\
\hline & & & Telmatobius chusmisensis & & no \\
\hline & & & Telmatobius cirrhacelis & & $4 \mathrm{n} / \mathrm{a}$ \\
\hline & & & Telmatobius colanensis & & 2 no \\
\hline & & & Telmatobius contrerasi & & $4 \mathrm{n} / \mathrm{a}$ \\
\hline & & & Telmatobius culeus & & 3 unknown \\
\hline & & & Telmatobius edaphonastes & & $4 \mathrm{n} / \mathrm{a}$ \\
\hline & & & Telmatobius espadai & & $4 \mathrm{n} / \mathrm{a}$ \\
\hline & & & Telmatobius hockingi & & 2 no \\
\hline & & & Telmatobius ignavus & & 2 no \\
\hline & & & Telmatobius jelskii & & unknown \\
\hline & & & Telmatobius laticeps & & $4 \mathrm{n} / \mathrm{a}$ \\
\hline & & & Telmatobius latirostris & & 2 unknown \\
\hline & & & Telmatobius marmoratus & & 2 yes \\
\hline & & & Telmatobius mayoloi & & 2 unknown \\
\hline & & & Telmatobius mendelsoni & & $4 \mathrm{n} / \mathrm{a}$ \\
\hline & & & Telmatobius niger & & $4 \mathrm{n} / \mathrm{a}$ \\
\hline & & & Telmatobius pefauri & & $4 \mathrm{n} / \mathrm{a}$ \\
\hline & & & Telmatobius pisanoi & & $4 \mathrm{n} / \mathrm{a}$ \\
\hline & & & Telmatobius punctatus & & no \\
\hline & & & Telmatobius sanborni & & 2 no \\
\hline
\end{tabular}




\begin{tabular}{|c|c|c|c|c|c|}
\hline \multirow[t]{11}{*}{ Order } & \multirow[t]{11}{*}{ Family } & \multirow[t]{11}{*}{ Genus } & \multirow{2}{*}{$\begin{array}{l}\text { Species } \\
\text { Telmatobius schreiteri }\end{array}$} & \multirow[t]{2}{*}{ Severity } & Recovery \\
\hline & & & & & $\mathrm{n} / \mathrm{a}$ \\
\hline & & & Telmatobius scrocchii & & $\mathrm{n} / \mathrm{a}$ \\
\hline & & & Telmatobius sibiricus & & $\mathrm{n} / \mathrm{a}$ \\
\hline & & & Telmatobius simonsi & & unknown \\
\hline & & & Telmatobius stephani & & $\mathrm{n} / \mathrm{a}$ \\
\hline & & & Telmatobius timens & & no \\
\hline & & & Telmatobius truebae & & no \\
\hline & & & Telmatobius vellardi & & no \\
\hline & & & Telmatobius verrucosus & & $\mathrm{n} / \mathrm{a}$ \\
\hline & & & Telmatobius yuracare & & $\mathrm{n} / \mathrm{a}$ \\
\hline \multirow[t]{30}{*}{ Caudata } & Ambystomatidae & Ambystoma & Ambystoma altamirani & & no \\
\hline & & & Ambystoma granulosum & & no \\
\hline & Plethodontidae & Bolitoglossa & Bolitoglossa biseriata & & unknown \\
\hline & & & Bolitoglossa colonnea & & unknown \\
\hline & & & Bolitoglossa compacta & & unknown \\
\hline & & & Bolitoglossa leandrae & & no \\
\hline & & & Bolitoglossa lignicolor & & unknown \\
\hline & & & Bolitoglossa magnifica & & unknown \\
\hline & & & Bolitoglossa marmorea & & unknown \\
\hline & & & Bolitoglossa medemi & & unknown \\
\hline & & & Bolitoglossa minutula & & unknown \\
\hline & & & Bolitoglossa rostrata & & no \\
\hline & & & Bolitoglossa schizodactyla & & unknown \\
\hline & & & Bolitoglossa tamaense & & no \\
\hline & & Chiropterotriton & Chiropterotriton dimidiatus & & no \\
\hline & & & Chiropterotriton magnipes & & no \\
\hline & & Oedipina & Oedipina grandis & & unknown \\
\hline & & & Oedipina parvipes & & unknown \\
\hline & & Parvimolge & Parvimolge townsendi & & no \\
\hline & & Pseudoeurycea & Pseudoeurycea brunnata & & $\mathrm{n} / \mathrm{a}$ \\
\hline & & & Pseudoeurycea cochranae & & no \\
\hline & & & Pseudoeurycea exspectata & & $\mathrm{n} / \mathrm{a}$ \\
\hline & & & Pseudoeurycea goebeli & & no \\
\hline & & & Pseudoeurycea lineola & & no \\
\hline & & & Pseudoeurycea melanomolga & & no \\
\hline & & & Pseudoeurycea nigromaculata & & no \\
\hline & & & Pseudoeurycea papenfussi & & no \\
\hline & & & Pseudoeurycea rex & & no \\
\hline & & & Pseudoeurycea smithi & & no \\
\hline & & & Pseudoeurycea unguidentis & & $\mathrm{n} / \mathrm{a}$ \\
\hline
\end{tabular}




\begin{tabular}{|c|c|c|c|c|c|}
\hline \multirow{8}{*}{\multicolumn{2}{|c|}{ Order Family }} & Genus & Species & Severity & Recovery \\
\hline & & \multirow[t]{7}{*}{ Thorius } & Thorius aureus & & 1 no \\
\hline & & & Thorius boreas & & 1 no \\
\hline & & & Thorius dubitis & & 3 no \\
\hline & & & Thorius magnipes & & 3 no \\
\hline & & & Thorius pennatulus & & 2 no \\
\hline & & & Thorius pulmonaris & & 2 no \\
\hline & & & Thorius troglodytes & & 3 no \\
\hline \multirow{2}{*}{\multicolumn{2}{|c|}{ Salamandridae }} & Euproctus & Euproctus platycephalus & & unknown \\
\hline & & Salamandra & Salamandra salamandra & & 1 no \\
\hline
\end{tabular}


Data S1. For the complete dataset of declined species, see the separate Excel file. 